\title{
Availability and dynamics of organic carbon and nitrogen indices in some soils amended with animal manures and ashes
}

\author{
Toyin B. Olowoboko ${ }^{1}$ ] . Jamiu O. Azeez ${ }^{1}$ (D) . Olanrewaju O. Olujimi ${ }^{2} \cdot$ Oluwatoyin A. Babalola $^{1}$
}

Received: 10 July 2017 / Accepted: 20 August 2018 / Published online: 30 August 2018

(c) The Author(s) 2018

\begin{abstract}
Purpose The study evaluated dried manures and manure ashes as alternative products from animal manures, and determined the dynamics of soil nitrogen availability indices and organic carbon release in some soils amended with dried manures and ashes under laboratory incubation, screen-house and field experiments.

Methods Cattle, goat and poultry manures were collected and air dried to produce dried manures after which part of the dried manures were burnt in open space at a temperature range of $320-450{ }^{\circ} \mathrm{C}$ to produce manure ashes. Treatments which were no amendment (control), dried manures of cattle, goat and poultry manure ashes of cattle, goat and poultry and NPK 15-1515 at $120 \mathrm{~kg} \mathrm{~N} \mathrm{ha}^{-1}$ were applied to soil. Samples were taken fortnightly after amendment incorporation in the incubation experiment; in screen-house experiment and field experiments, plant seeds were established after amendment incorporation; thereafter, soil samples were taken fortnightly. Soil samples were analyzed for soil organic carbon ( $\mathrm{SOC}$ ), $\mathrm{NH}_{4}{ }^{+}-\mathrm{N}_{\text {and }}$ $\mathrm{NO}_{3}{ }^{-}-\mathrm{N}$ using a spectrophotometer.

Results Incineration of manures increased $\mathrm{pH}$, exchangeable cations and carbon, while nitrogen in manures ashes was comparable to nitrogen in dried manures. The application of manure ash increased $\mathrm{SOC}, \mathrm{NH}_{4}{ }^{-}-\mathrm{N}^{-}$and $\mathrm{NO}_{3}{ }^{-}-\mathrm{N}$ by 182,102 , $128 \%$ in incubation experiment while 64 and $628 \%$ increase in $\mathrm{SOC}$ and $\mathrm{NH}_{4}{ }^{+}-\mathrm{N}$ was recorded in screen-house experiment, respectively, relative to the control. In the field experiment, a significant increase in $\mathrm{NO}_{3}{ }^{-} \mathrm{N}$ was recorded at the onset of incorporation; nitrification was more pronounced than ammonification under incubation and field conditions.

Conclusion Dried manures are not superior to manure ashes and incorporation of manures ashes increased the $\mathrm{SOC}, \mathrm{NH}_{4}{ }^{+}-\mathrm{N}$ and $\mathrm{NO}_{3}{ }^{-}-\mathrm{N}$ though changes with increasing weeks were erratic.
\end{abstract}

Keywords Nitrification $\cdot$ Nitrogen availability indices $\cdot$ Nutrient dynamics $\cdot$ Soil organic carbon

Toyin B. Olowoboko

rachy_blare26@yahoo.com

Jamiu O. Azeez

azeezjo@funaab.edu.ng

Olanrewaju O. Olujimi

olujimio@funaab.edu.ng

Oluwatoyin A. Babalola

babalolaoa@funaab.edu.ng

1 Department of Soil Science and Land Management, Federal University of Agriculture Abeokuta, Abeokuta, Nigeria

2 Department of Environmental Management and Toxicology, Federal University of Agriculture Abeokuta, Abeokuta, Ogun state, Nigeria

\section{Introduction}

There is recent interest in the use of agricultural wastes by dominant resource poor farmers in sub-Saharan Africa. Farm wastes such as crop residues and animal excreta are used directly or composted (Ayeni and Adeleye 2008) for cop production. Incorporation of organic matter through farmyard manure has been shown to improve soil structure, water retention capacity, infiltration rate, hydraulic conductivity and decrease bulk density (Edmeades 2003). Organic manures have also been reported to enhance nutrient use efficiency and reduce the need for chemical fertilizers, to improve the soil fertility and soil health (Hao et al. 2008). More recently, Law-Ogbomo et al. (2011) recorded improved nitrogen, phosphorus, potassium, calcium, and organic carbon status of the soil treated with poultry manure. 
Soil organic carbon (SOC) refers only to the carbon component of organic compounds; it includes the microbial biomass and slow and passive humus pools, but not residue or litter (Griffin et al. 2013). Soil organic matter is closely related to soil carbon and the product of its decomposition is humus. Humus is a major determinant of soil cation exchange capacity, particularly in weathered soils of sub-Saharan Africa. Nitrogen is a major soil nutrient and closely related to soil carbon; it is a determinant nutrient for plant growth (Hossain et al. 2007). Soil nitrogen forms depend primarily on the processes of immobilization and organic matter mineralization and its supply through animal manures is transformed by microbial activity from organic nitrogen to ammonium and further on to nitrate by nitrification during mineralization. The turnover of manure $\mathrm{N}$ in the soil, mineralization-immobilization process and subsequent $\mathrm{N}$ availability for plant growth are all influenced by manure composition (Chadwick et al. 2000).

Hence, in order to predict the net mineralization of nitrogen in animal manures, transformation of nitrogen from organic into inorganic form and immobilization processes need to be understood (Saka et al. 2017) since these processes are mediated through microbial activities and could be biochemical (Vel and Swarnam 2013).

Animal wastes are abundant all over the world with Nigeria producing about 227,500 tons of fresh waste each day (Oyeleke et al. 2003). Due to the large amount of the wastes being produced, they are increasingly being regarded as an industrial waste that needs to be managed in an environmentally sound manner since they cannot be continuously applied to land because the volume of its generation exceeds usage (Ksawery et al. 2012). The incineration of animal manure is an option to effectively reduce the volume, concentrate fertilizer nutrients and remove offensive odor, though some nitrogen might also be lost to volatilization (Yusiharni et al. 2007). The difficulty in the prediction of manure nutrients to plants is due to turnover processes and microbial mediated changes in nutrient dynamics of the manures (Azeez and Van Averbeke 2010). Hence, a more predictable trend could be gotten when the manure is ashed and its contents changed to a product more inorganic. Therefore, incorporation of animal manures and their ashes as timely to supply carbon and nitrogen without posing any injury to soil and plants is very important in soil nutrients replenishment to support crop production; this necessitated the research to

1. Characterize dried manures and their ashes.

2. Evaluate the effect of dried manures and ashes on organic carbon, ammonium nitrogen and nitrate nitrogen in some soils of Abeokuta under incubation (laboratory), screen-house and field conditions.

3. Determine the dynamics of soil nitrate, ammonium and organic carbon from different animal manures and their ashes in incubation (laboratory), screen-house and field conditions.

\section{Materials and methods}

\section{Soil collection and analysis}

The top soil samples $(0-20 \mathrm{~cm})$ were collected from four locations in Ogun state in a forest-savanna transitional ecological zone. Samples from Alabata and Osiele are classified as Arenic Paleudalf (Adetunji 1991) from basement complex while samples from Itori and Papalanto are Oxic Tropodaulf from sedimentary parent materials. The soils were air dried to constant weight at room temperature $\left(23-27{ }^{\circ} \mathrm{C}\right)$ and sieved with $2 \mathrm{~mm}$ mesh sieve. Sub-samples from the soils were collected and analyzed for the following properties: Soil $\mathrm{pH}$ was estimated in 1:2 (soil:water) using glass electrode $\mathrm{pH}$ meter (Orion research model 201) and electrical conductivity was estimated in 1:5 (soil:water) with an EC 215 conductivity meter (Hanna instrument) according to Kaira and Maynard (1991). Particle size was determined by hydrometer method (Bouyoucos 1965). Total nitrogen was analyzed using Kjeldahl method. Organic carbon was determined colorimetrically according to Baker (1976). Exchangeable cations were extracted with $1 \mathrm{~N}$ ammonium acetate; $\mathrm{Na}$ and $\mathrm{K}$ in the extract were determined by flame photometry, while $\mathrm{Ca}$ and $\mathrm{Mg}$ were determined by atomic absorption spectrophotometer. Ammonium nitrogen and nitrate nitrogen were determined spectrophotometrically (UV-3200 PCS spectrophotometer) according to Cataldo et al. (1975).

\section{Manure collection and analysis}

Cattle, goat and poultry manures were collected from the Federal University of Agriculture, Alabata (FUNAAB) farm and air dried to produce dried manures, while part of the dried manures was burnt in open space at a temperature range of $320-450{ }^{\circ} \mathrm{C}$ to produce manure ash. Dried manures were homogenized with a hammer mill after which $\mathrm{pH}$, exchangeable bases, total nitrogen and total organic carbon were determined according to Cataldo et al. (1975).

\section{Experimental design}

Incubation and screen-house experiments were laid out in completely randomized design while the field experiment was laid out in randomized complete block design. The experiments were replicated thrice with eight treatments which included no amendment (control), dried cattle manure (DCM), dried goat manure (DGM), dried poultry manure (DPM), cattle manure ash (CMA), goat manure ash (GMA), poultry manure ash (PMA) and NPK 15-15-15 applied at120 $\mathrm{kg} \mathrm{N} \mathrm{ha}^{-1}$. 


\section{Laboratory incubation}

The photograph of the laboratory incubation is given in Fig. 1. One hundred grams of air-dried soil (collected from the four locations-Alabata, Osiele, Itori and Papalanto) which had passed through $2 \mathrm{~mm}$ sieve was dispensed into $200 \mathrm{~g}$ capacity plastic and tightly covered. Dried manure, their ashes and NPK were applied at a rate of $120 \mathrm{~kg} \mathrm{~N} \mathrm{ha}^{-1}$ separately into each plastic and mixed. The rate applied is equivalent to $0.04 \mathrm{~g}$ NPK, $2.06 \mathrm{~g}$ CMA, $1.99 \mathrm{~g}$ GMA, $2.23 \mathrm{~g}$ PMA, $1.68 \mathrm{~g}$ DCM, $1.58 \mathrm{~g}$ DGM and $1.49 \mathrm{~g}$ DPM. The soil and amendment mixture were watered to field capacity and kept in a dark cupboard for 8 weeks. Occasionally, the moisture content was adjusted to field capacity by adding distilled water. Temperature of the incubation cupboard was determined daily with a thermometer and average temperature of $27.5^{\circ} \mathrm{C}$ was recorded. Soil samples were taken at 0 , 2, 4, 6, 8 weeks of incubation and analyzed for ammonium nitrogen, nitrate nitrogen and organic carbon content according to method described earlier.

\section{Screen-house experiment}

This was a two cycle experiment in a screen-house (made of mesh). In the first cycle, five kilograms of soil from two locations (Alabata and Papalanto) was dispensed into pots with treatment applied as mentioned earlier. The rate applied is equivalent to $1.79 \mathrm{~g} \mathrm{NPK}, 103.00 \mathrm{~g} \mathrm{CMA}, 99.25 \mathrm{~g}$ GMA, 116.50 g PMA, 83.75 g DCM, 78.80 g DGM and $74.40 \mathrm{~g}$ DPM. The soil samples in the pots were watered to field capacity and three seeds of maize (BR-9928-DMRSR-Y) were sown per pot. The plants were thinned to one plant per pot after 2 weeks. The plants were watered when necessary and monitored in the screen-house for 8 weeks. Soil samples were also taken at $0,2,4,6$ and 7 weeks after planting. Soil samples were taken from the pots by collecting samples round the plant root at $0-15 \mathrm{~cm}$ depth with the

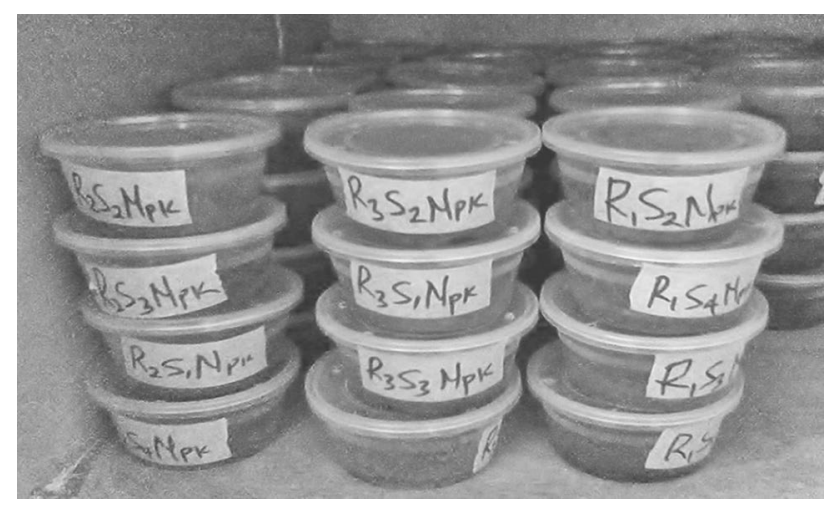

Fig. 1 Photograph of laboratory incubation aid of a calibrated spoon, after which samples were bulked to become a representative sample from each pot. Collected soil samples were analyzed for ammonium nitrogen, nitrate nitrogen and organic carbon. This process was repeated in the second maize cycle but soil samples were only collected at 0,4 and 6 weeks after planting.

\section{Field experiment}

This experiment was carried out at the Teaching and Research Farms, Federal University of Agriculture (FUNAAB), Abeokuta Ogun state Nigeria. Dried manure treatments were applied manually 2 weeks before planting. Manure ashes treatments and NPK fertilizer were applied 2 weeks after planting. The rate applied is equivalent to $0.93 \mathrm{~kg}$ NPK, $55.38 \mathrm{~kg}$ CMA, $53.33 \mathrm{~kg}$ GMA, $60.00 \mathrm{~kg}$ PMA, $45.00 \mathrm{~kg}$ DCM, $42.35 \mathrm{~kg}$ DGM and $40.00 \mathrm{~kg}$ DPM to plots of $3 \mathrm{~m}$ by $4 \mathrm{~m}$ dimension. Maize seeds were sown at a spacing of $25 \mathrm{~cm}$ by $75 \mathrm{~cm}$. Soil samples were taken at $0,2,4,6,8,10$ weeks after planting. Soil samples were collected randomly within plot at a depth of $0-15 \mathrm{~cm}$ after which samples were bulked as a representative sample of each plot. Collected soil samples were analyzed for ammonium nitrogen, nitrate nitrogen and organic carbon.

\section{Statistical analysis}

Data collected were analyzed for their variance by using the software package SAS (1999). Significant treatments were separated using LSD at 5\% level of probability.

\section{Results}

\section{Soil characteristics}

Characterizations of experimental soils are shown in Table 1. The $\mathrm{pH}$ of soils used for the experiment ranged from 7.63 in Itori to 6.07 in FUNAAB. Electrical conductivity values were $0.38,0.43,0.73,0.26$ and $0.40 \mathrm{dS} \mathrm{m}^{-1}$ in soils from Alabata, Osiele, Itori, Papalanto and FUNAAB, respectively. Calcium and sodium were highest in soil from Itori while the lowest values were observed in Papalanto. Magnesium ranged from $2.21 \mathrm{cmol} \mathrm{kg}^{-1}$ in soil from Osiele to $1.05 \mathrm{cmol} \mathrm{kg}^{-1}$ in soil from Alabata while potassium ranged from $0.39 \mathrm{cmol} \mathrm{kg}^{-1}$ in FUNAAB to $0.18 \mathrm{cmol}$ $\mathrm{kg}^{-1}$ in soil from Papalanto. Total N in FUNAAB soil was $0.25 \%$; this is followed by $0.23 \%$ in Itori, $0.21 \%$ in Alabata, $0.19 \%$ in Osiele and $0.18 \%$ Papalanto. Value of total organic carbon was highest in Osiele $\left(55.9 \mathrm{~g} \mathrm{~kg}^{-1}\right)$, and the lowest in Itori $\left(43.7 \mathrm{~g} \mathrm{~kg}^{-1}\right)$. All the experimental soils are loamy sandy except soil from Papalanto which is sandy in texture. 
Table 1 Characterization of experimental soils, dried manures and manure ashes

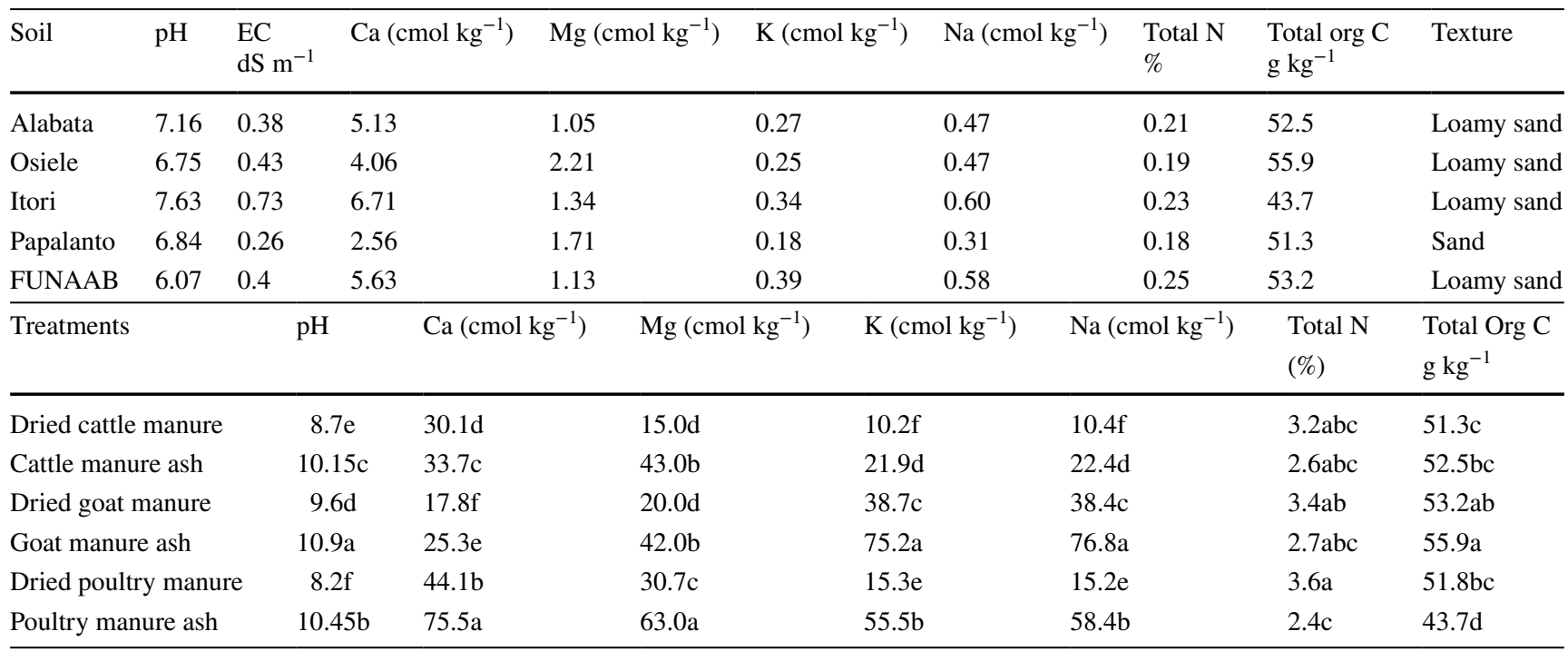

Means with the same letter(s) within the same column are not significantly different at $p<0.05$

\section{Characterization of dried manures and manure ash}

Characteristics of dried manure and manure ashes are shown in Table 1. The $\mathrm{pH}$ values ranged from 10.90 in GMA to 8.20 in DPM. $\mathrm{pH}$ values of manure ashes were in the order of GMA $>$ PMA $>$ CMA while the $\mathrm{pH}$ of dried manures were in the order of DGM $>$ DCM $>$ DPM.

The equivalent amount of calcium, magnesium, potassium and sodium content of dried manures is $30.1,15.0$, $10.20,10.4 \mathrm{cmol} \mathrm{kg}^{-1}$ for DCM, 17.8, 20.0, 38.7, 38.4 $\mathrm{cmol} \mathrm{kg}{ }^{-1}$ for DGM and 44.1, 30.7, 15.3, $15.2 \mathrm{cmol} \mathrm{kg}^{-1}$ for DPM while the values for manures ashes were 33.7, 43.0, 21.9, $22.4 \mathrm{cmol} \mathrm{kg}^{-1}$ for CMA, 25.3, 42.0, 75.2, 76.8 $\mathrm{cmol} \mathrm{kg}^{-1}$ for GMA and 75.5, 63.0, 55.5, $58.4 \mathrm{cmol} \mathrm{kg}^{-1}$ for PMA. There was no significant difference in values of total organic carbon (TOC) of dried manures and manures ashes except in poultry manure ash TOC was $33 \%$ lower compared with its dried manure. Dried poultry manure had the highest total nitrogen followed by dried goat manure and dried cattle manure. Total organic carbon was in the order of GMA $>$ D $\mathrm{GM}>\mathrm{CMA}>\mathrm{DPM}>\mathrm{DCM}>\mathrm{PMA}$.

\section{Effect of amendments on soil organic carbon (SOC)}

Table 2 shows that during incubation experiment, no significant differences were observed among dried manures and manure ashes in soil from Alabata at 0 weeks after incorporation (0 WAI), though soil organic carbon (SOC) increased with the application of manure ashes and dried manures except in dried cattle manure relative to the control. At 2 WAI, application of NPK produced significantly higher SOC (182\%) than the control and manure amendments. However, the effect of the amendments was not significant at 0 and 4
WAI in soil collected from Osiele. Effect of manure ashes on the SOC did not differ significantly from their dried manures during the period of observation, although SOC was numerically higher with the application of manure ashes in comparison to their dried manures at $2 \mathrm{WAI}$ in soil collected from Osiele. Soil from Itori amended with DCM had the highest SOC of $112.5 \mathrm{~g} \mathrm{~kg}^{-1}$, which was significantly higher than other amendments and the control (Table 3).

In the first cycle of the screen-house experiment (Table 4), soil from Alabata released significantly higher SOC when applied with DGM. However, control, GMA and DPM had similar effect while DCM, PMA and NPK did not differ from one another. Manure ashes with the exception of PMA differed from their dried manures and a significant increase of $23 \%$ and decrease of $29 \%$ were recorded in CMA and GMA, respectively, relative to their dried manures at 0 WAI. However, the effect of the amendment was not noticeable in the second cycle of the experiment because no significant difference was observed in amended soil relative to control soil. In Papalanto, the value of SOC in control soil did not differ from amended soils at 0 and $4 \mathrm{WAI}$ in the 1 st cycle of screen-house experiment. More organic carbon was released from manure ashes when compared with their dried manures at $0 \mathrm{WAI}$, while dried manure increased SOC than manure ashes at 4 WAI. Application of PMA significantly increased SOC at 2 and 8 WAI.

\section{Dynamics of soil organic carbon}

The amount of SOC released had an inconsistent pattern with increasing weeks for amendment and control (Tables 2, 3, 4 and 5); when high organic carbon is released at a particular week, there is a reduction in release at the succeeding 
Table 2 Effect of amendments and incubation time on soil organic carbon (SOC) of soils from Alabata and Osiele

\begin{tabular}{lrrllll}
\hline Treatments & 0 WAI & 2 WAI & $\begin{array}{l}\text { SOC } \\
4 \text { WAI }\end{array}$ & $\begin{array}{l}\left(\mathrm{g} \mathrm{kg}^{-1}\right) \\
6 \mathrm{WAI}\end{array}$ & 8 WAI & Lsd \\
\hline Alabata & & & & & & \\
Control & $63.3 \mathrm{a}$ & $44.0 \mathrm{~b}$ & $65.6 \mathrm{bcd}$ & $40.4 \mathrm{bc}$ & $82.4 \mathrm{a}$ & 13.3 \\
Dried cattle manure & $57.2 \mathrm{a}$ & $70.0 \mathrm{~b}$ & $81.4 \mathrm{ab}$ & $47.4 \mathrm{a}$ & $75.7 \mathrm{ab}$ & 28.0 \\
Cattle manure ash & $101.3 \mathrm{a}$ & $62.1 \mathrm{~b}$ & $74.7 \mathrm{abc}$ & $36.4 \mathrm{c}$ & $65.3 \mathrm{ab}$ & 74.3 \\
Dried goat manure & $63.7 \mathrm{a}$ & $56.7 \mathrm{~b}$ & $87.8 \mathrm{a}$ & $40.8 \mathrm{bc}$ & $66.7 \mathrm{ab}$ & 24.0 \\
Goat manure ash & $64.7 \mathrm{a}$ & $56.7 \mathrm{~b}$ & $63.3 \mathrm{bcd}$ & $39.3 \mathrm{bc}$ & $77.7 \mathrm{ab}$ & 24.0 \\
Dried poultry manure & $104.6 \mathrm{a}$ & $62.6 \mathrm{~b}$ & $61.7 \mathrm{~cd}$ & $43.9 \mathrm{abc}$ & $79.3 \mathrm{ab}$ & 11.2 \\
Poultry manure ash & $65.3 \mathrm{a}$ & $52.8 \mathrm{~b}$ & $61.2 \mathrm{~cd}$ & $41.6 \mathrm{bc}$ & $61.2 \mathrm{~b}$ & 18.9 \\
NPK (15-15-15) & $80.2 \mathrm{a}$ & $124.2 \mathrm{a}$ & $53.0 \mathrm{~d}$ & $41.6 \mathrm{bc}$ & $59.8 \mathrm{~b}$ & 13.3 \\
Osiele & & & & & & \\
Control & $71.3 \mathrm{a}$ & $57.7 \mathrm{ab}$ & $67.2 \mathrm{a}$ & $61.3 \mathrm{~b}$ & $69.4 \mathrm{ab}$ & 11.7 \\
Dried cattle manure & $72.6 \mathrm{a}$ & $54.6 \mathrm{~b}$ & $70.6 \mathrm{a}$ & $49.5 \mathrm{~cd}$ & $81.2 \mathrm{ab}$ & 23.5 \\
Cattle manure ash & $101.4 \mathrm{a}$ & $70.9 \mathrm{ab}$ & $69.1 \mathrm{a}$ & $48.1 \mathrm{~d}$ & $74.8 \mathrm{ab}$ & 48.9 \\
Dried goat manure & $80.0 \mathrm{a}$ & $60.7 \mathrm{ab}$ & $86.9 \mathrm{a}$ & $50.0 \mathrm{~cd}$ & $98.0 \mathrm{a}$ & 31.7 \\
Goat manure ash & $87.5 \mathrm{a}$ & $75.3 \mathrm{a}$ & $91.0 \mathrm{a}$ & $55.1 \mathrm{bcd}$ & $81.4 \mathrm{ab}$ & 28.0 \\
Dried poultry manure & $65.6 \mathrm{a}$ & $59.9 \mathrm{ab}$ & $83.3 \mathrm{a}$ & $57.5 \mathrm{bc}$ & $86.4 \mathrm{ab}$ & 34.9 \\
Poultry manure ash & $73.6 \mathrm{a}$ & $65.9 \mathrm{ab}$ & $74.3 \mathrm{a}$ & $49.0 \mathrm{~cd}$ & $68.2 \mathrm{~b}$ & 11.5 \\
NPK (15-15-15) & $67.2 \mathrm{a}$ & $65.1 \mathrm{ab}$ & $91.9 \mathrm{a}$ & $72.8 \mathrm{a}$ & $72.5 \mathrm{ab}$ & 38.4 \\
\hline
\end{tabular}

Means with the same letter(s) within the same column are significantly different at $p<0.05$

$W A I$ weeks after incorporation, $L s d$ differences across the weeks for each treatment

\begin{tabular}{lccclcc}
\hline Treatment & OWAI & 2 WAI & $\begin{array}{l}\text { SOC } \\
4 \text { WAI }\end{array}$ & $\begin{array}{l}\left(\mathrm{g} \mathrm{kg}^{-1}\right) \\
6 \text { WAI }\end{array}$ & 8 WAI & Lsd \\
\hline Itori & & & & & & \\
Control & $90.1 \mathrm{ab}$ & $56.0 \mathrm{bc}$ & $55.8 \mathrm{~b}$ & $60.8 \mathrm{ab}$ & $67.7 \mathrm{~d}$ & 26.0 \\
Dried cattle manure & $112.5 \mathrm{a}$ & $52.1 \mathrm{c}$ & $92.6 \mathrm{ab}$ & $52.4 \mathrm{~b}$ & $96.3 \mathrm{abc}$ & 30.0 \\
Cattle manure ash & $61.9 \mathrm{c}$ & $64.4 \mathrm{bc}$ & $157.5 \mathrm{a}$ & $62.1 \mathrm{ab}$ & $78.6 \mathrm{bcd}$ & 29.0 \\
Dried goat manure & $70.4 \mathrm{bc}$ & $67.2 \mathrm{bc}$ & $115.9 \mathrm{ab}$ & $77.9 \mathrm{a}$ & $107.4 \mathrm{a}$ & 81.6 \\
Goat manure ash & $73.3 \mathrm{bc}$ & $124.6 \mathrm{a}$ & $104.3 \mathrm{ab}$ & $47.1 \mathrm{~b}$ & $75.2 \mathrm{~cd}$ & 32.1 \\
Dried poultry manure & $71.0 \mathrm{bc}$ & $70.1 \mathrm{bc}$ & $72.5 \mathrm{~b}$ & $53.4 \mathrm{~b}$ & $80.0 \mathrm{bcd}$ & 15.7 \\
Poultry manure ash & $66.3 \mathrm{bc}$ & $132.2 \mathrm{a}$ & $91.0 \mathrm{ab}$ & $59.1 \mathrm{ab}$ & $76.6 \mathrm{~cd}$ & 50.1 \\
NPK (15-15-15) & $85.1 \mathrm{bc}$ & $78.8 \mathrm{~b}$ & $90.0 \mathrm{ab}$ & $55.5 \mathrm{ab}$ & $101.0 \mathrm{ab}$ & 26.4 \\
Papalanto & & & & & & \\
Control & $68.3 \mathrm{abc}$ & $52.1 \mathrm{~b}$ & $71.8 \mathrm{a}$ & $37.5 \mathrm{c}$ & $77.5 \mathrm{ab}$ & 27.6 \\
Dried cattle manure & $62.7 \mathrm{abc}$ & $54.1 \mathrm{~b}$ & $68.1 \mathrm{a}$ & $47.2 \mathrm{bc}$ & $74.4 \mathrm{ab}$ & 16.6 \\
Cattle manure ash & $62.3 \mathrm{abc}$ & $54.4 \mathrm{~b}$ & $81.4 \mathrm{a}$ & $37.6 \mathrm{c}$ & $56.8 \mathrm{~b}$ & 27.3 \\
Dried goat manure & $58.9 \mathrm{bc}$ & $62.2 \mathrm{~b}$ & $63.5 \mathrm{a}$ & $51.5 \mathrm{ab}$ & $77.6 \mathrm{ab}$ & 18.1 \\
Goat manure ash & $53.4 \mathrm{c}$ & $64.5 \mathrm{~b}$ & $91.0 \mathrm{a}$ & $64.2 \mathrm{a}$ & $80.0 \mathrm{ab}$ & 27.0 \\
Dried poultry manure & $84.1 \mathrm{a}$ & $52.1 \mathrm{~b}$ & $83.7 \mathrm{a}$ & $64.5 \mathrm{a}$ & $60.4 \mathrm{~b}$ & 20.5 \\
Poultry manure ash & $80.2 \mathrm{ab}$ & $98.6 \mathrm{a}$ & $77.0 \mathrm{a}$ & $61.6 \mathrm{a}$ & $101.5 \mathrm{a}$ & 62.9 \\
NPK (15-15-15) & $69.3 \mathrm{abc}$ & $85.7 \mathrm{a}$ & $90.5 \mathrm{a}$ & $48.9 \mathrm{abc}$ & $57.1 \mathrm{~b}$ & 19.0 \\
\hline
\end{tabular}

Means with the same letter(s) within the same column are significantly different at $p<0.05$

$W A I$ weeks after incorporation, $L s d$ differences across the weeks for each treatment
Table 3 Effect of amendments and incubation time on organic carbon of soils from Itori and Papalanto week. With the application of DCM, the highest and the lowest amount of SOC were released at 4 and $6 \mathrm{WAI}$, respectively, in the soil from Alabata during incubation experiment
(Table 2). SOC decreased significantly by $42 \%$ at 4 WAI and increased again at $60 \%$ at 8 WAI. Similar trend was observed in soil from Osiele. In soil from Itori (Table 3), the 
Table 4 Effect of amendments and time on organic carbon of soils from Alabata and Papalanto in screen-house experiment

\begin{tabular}{|c|c|c|c|c|c|c|c|c|c|c|}
\hline \multirow[t]{2}{*}{ Treatments } & \multirow[b]{2}{*}{$0 \mathrm{WAI}$} & \multicolumn{2}{|l|}{$\mathrm{SOC}\left(\mathrm{g} \mathrm{kg}^{-1}\right)$} & \multicolumn{2}{|l|}{ Cycle 1} & \multirow[t]{2}{*}{$\mathrm{Lsd}^{*}$} & \multirow{2}{*}{$\begin{array}{l}\text { SOC } \\
0 \text { WAI }\end{array}$} & \multirow{2}{*}{$\begin{array}{l}\left(\mathrm{g} \mathrm{kg}^{-1}\right) \\
4 \text { WAI }\end{array}$} & \multirow{2}{*}{$\begin{array}{l}\text { Cycle } 2 \\
6 \text { WAI }\end{array}$} & \multirow[t]{2}{*}{$\operatorname{Lsd}^{* *}$} \\
\hline & & $2 \mathrm{WAI}$ & 4 WAI & $6 \mathrm{WAI}$ & 7 WAI & & & & & \\
\hline \multicolumn{11}{|l|}{ Alabata } \\
\hline Control & $89.8 b$ & $63.0 \mathrm{~cd}$ & $64.5 b$ & $82.1 \mathrm{ab}$ & $70.0 \mathrm{ab}$ & 17.1 & $67.7 \mathrm{a}$ & $52.2 \mathrm{a}$ & $58.0 \mathrm{a}$ & 1.75 \\
\hline Dried cattle manure & $73.1 \mathrm{c}$ & $84.1 \mathrm{ab}$ & $68.6 b$ & $67.2 \mathrm{ab}$ & $67.7 \mathrm{ab}$ & 17.2 & $68.6 \mathrm{a}$ & $68.6 \mathrm{a}$ & $55.2 \mathrm{a}$ & 1.70 \\
\hline Cattle manure ash & $89.7 b$ & $66.3 \mathrm{~cd}$ & $69.1 \mathrm{~b}$ & $99.2 \mathrm{a}$ & $68.6 \mathrm{ab}$ & 47.5 & $66.7 \mathrm{a}$ & $54.9 \mathrm{a}$ & $54.7 \mathrm{a}$ & 0.37 \\
\hline Dried goat manure & $105.2 \mathrm{a}$ & $82.3 \mathrm{ab}$ & $93.8 b$ & $76.0 \mathrm{ab}$ & $66.7 \mathrm{ab}$ & 35.2 & $69.5 \mathrm{a}$ & $62.1 \mathrm{a}$ & $57.6 \mathrm{a}$ & 0.96 \\
\hline Goat manure ash & $75.2 \mathrm{bc}$ & $71.6 \mathrm{bc}$ & $67.7 b$ & $56.2 b$ & $82.1 \mathrm{a}$ & 37.1 & $67.7 \mathrm{a}$ & $58.5 \mathrm{a}$ & $55.2 \mathrm{a}$ & 1.62 \\
\hline Dried poultry manure & $75.7 \mathrm{bc}$ & $66.7 \mathrm{c}$ & $71.5 b$ & $57.0 \mathrm{~b}$ & $75.1 \mathrm{ab}$ & 25.3 & $75.1 \mathrm{a}$ & $57.6 \mathrm{a}$ & $62.5 \mathrm{a}$ & 2.70 \\
\hline Poultry manure ash & $67.7 \mathrm{c}$ & $93.8 \mathrm{a}$ & $148.8 \mathrm{a}$ & $59.8 \mathrm{ab}$ & $72.4 \mathrm{ab}$ & 21.2 & $72.4 \mathrm{a}$ & $59.5 \mathrm{a}$ & $64.4 \mathrm{a}$ & 3.21 \\
\hline NPK (15-15-15) & $68.2 \mathrm{c}$ & $51.0 \mathrm{~d}$ & $90.6 b$ & $67.3 \mathrm{ab}$ & $58.0 \mathrm{~b}$ & 39.5 & $58.0 \mathrm{a}$ & $67.4 \mathrm{a}$ & $51.3 \mathrm{a}$ & 2.99 \\
\hline \multicolumn{11}{|l|}{ Papalanto } \\
\hline Control & $123.8 \mathrm{a}$ & $75.6 \mathrm{bcd}$ & $78.0 \mathrm{a}$ & $82.5 \mathrm{ab}$ & $67.4 \mathrm{bc}$ & 65.8 & $67.4 \mathrm{ab}$ & $67.2 \mathrm{ab}$ & $66.4 \mathrm{a}$ & 2.97 \\
\hline Dried cattle manure & $80.8 \mathrm{a}$ & $80.1 \mathrm{bc}$ & $83.6 \mathrm{a}$ & $76.2 \mathrm{abc}$ & $68.6 \mathrm{ab}$ & 15.7 & $68.6 \mathrm{ab}$ & $63.0 \mathrm{ab}$ & $66.9 \mathrm{a}$ & 1.99 \\
\hline Cattle manure ash & $119.6 \mathrm{a}$ & $66.5 \mathrm{~d}$ & $59.8 \mathrm{a}$ & $78.5 \mathrm{abc}$ & 74.3abc & 19.8 & $74.3 \mathrm{ab}$ & $63.3 \mathrm{ab}$ & $61.8 \mathrm{a}$ & 1.44 \\
\hline Dried goat manure & $89.6 \mathrm{a}$ & $86.0 \mathrm{~b}$ & $76.2 \mathrm{a}$ & $86.8 \mathrm{a}$ & $81.8 \mathrm{abc}$ & 23.0 & $81.8 \mathrm{a}$ & $72.1 \mathrm{a}$ & $59.1 \mathrm{a}$ & 2.10 \\
\hline Goat manure ash & $89.4 \mathrm{a}$ & $83.8 \mathrm{bc}$ & $74.4 \mathrm{a}$ & $71.2 \mathrm{abc}$ & $66.0 \mathrm{bc}$ & 14.6 & $66.0 \mathrm{ab}$ & $62.3 \mathrm{ab}$ & $64.7 \mathrm{a}$ & 0.93 \\
\hline Dried poultry manure & $84.6 \mathrm{a}$ & $82.9 \mathrm{bc}$ & $80.5 \mathrm{a}$ & $64.9 \mathrm{bc}$ & $89.2 \mathrm{ab}$ & 17.5 & $76.3 \mathrm{ab}$ & $68.1 \mathrm{ab}$ & $72.5 \mathrm{a}$ & 1.28 \\
\hline Poultry manure ash & $88.2 \mathrm{a}$ & $131.2 \mathrm{a}$ & $75.4 \mathrm{a}$ & $63.3 \mathrm{c}$ & $92.0 \mathrm{a}$ & 19.6 & $76.1 \mathrm{ab}$ & $62.8 \mathrm{ab}$ & $71.0 \mathrm{a}$ & 3.27 \\
\hline NPK (15-15-15) & $80.3 \mathrm{a}$ & $72.8 \mathrm{~cd}$ & $76.8 \mathrm{a}$ & $66.0 \mathrm{bc}$ & $64.6 \mathrm{c}$ & 26.2 & $64.6 \mathrm{~b}$ & $54.3 b$ & $61.6 \mathrm{a}$ & 1.33 \\
\hline
\end{tabular}

Means with the same letter(s) within the same column are significantly different at $p<0.05$

WAI weeks after incorporation

*Differences across the weeks for each treatment in cycle 1

**Differences across the weeks for each treatment in cycle 2

Table 5 Effect of amendments and time on organic carbon of soil in field experiment

\begin{tabular}{lccccccc}
\hline Treatments & 0 WAI & 2 WAI & $\begin{array}{l}\text { SOC } \\
\text { 4 WAI }\end{array}$ & $\begin{array}{l}\left(\mathrm{g} \mathrm{kg}^{-1}\right) \\
6 \text { WAI }\end{array}$ & 8 WAI & 10 WAI & Lsd** \\
\hline Control & $59.9 \mathrm{~b}$ & $127.0 \mathrm{a}$ & $60.3 \mathrm{~b}$ & $49.5 \mathrm{c}$ & $63.5 \mathrm{a}$ & $76.2 \mathrm{a}$ & 20.9 \\
Dried cattle manure & $73.7 \mathrm{~b}$ & $77.5 \mathrm{~b}$ & $104.0 \mathrm{a}$ & $71.7 \mathrm{ab}$ & $75.4 \mathrm{a}$ & $83.7 \mathrm{a}$ & 46.7 \\
Cattle manure ash & $57.4 \mathrm{~b}$ & $65.9 \mathrm{bc}$ & $58.1 \mathrm{~b}$ & $61.9 \mathrm{abc}$ & $67.5 \mathrm{a}$ & $75.6 \mathrm{a}$ & 15.1 \\
Dried goat manure & $84.2 \mathrm{~b}$ & $68.4 \mathrm{bc}$ & $59.4 \mathrm{~b}$ & $70.0 \mathrm{abc}$ & $69.8 \mathrm{a}$ & $89.4 \mathrm{a}$ & 19.7 \\
Goat manure ash & $82.3 \mathrm{~b}$ & $68.1 \mathrm{bc}$ & $52.5 \mathrm{~b}$ & $48.8 \mathrm{c}$ & $63.5 \mathrm{a}$ & $65.4 \mathrm{a}$ & 22.3 \\
Dried poultry manure & $115.7 \mathrm{a}$ & $66.0 \mathrm{bc}$ & $80.5 \mathrm{ab}$ & $74.2 \mathrm{a}$ & $67.8 \mathrm{a}$ & $74.9 \mathrm{a}$ & 21.8 \\
Poultry manure ash & $63.5 \mathrm{~b}$ & $67.0 \mathrm{bc}$ & $69.0 \mathrm{ab}$ & $58.9 \mathrm{abc}$ & $64.1 \mathrm{a}$ & $78.9 \mathrm{a}$ & 17.5 \\
NPK (15-15-15) & $79.3 \mathrm{~b}$ & $59.8 \mathrm{c}$ & $56.2 \mathrm{~b}$ & $51.3 \mathrm{bc}$ & $59.4 \mathrm{a}$ & $67.8 \mathrm{a}$ & 19.4 \\
\hline
\end{tabular}

Means with the same letter(s) within the same column are significantly different at $p<0.05$

WAI weeks after incorporation

**Differences across the weeks for each treatment amount of SOC released fortnightly differed significantly. Table 2 shows that with the application of CMA, soil from Alabata did not differ in the amount of organic carbon content released during the period of observation. The highest and the lowest values were recorded at 0 and $6 \mathrm{WAI}$, respectively, during incubation. Similar response was observed in soil from Osiele only that a significant reduction of $52 \%$ was observed at 6 WAI relative to $0 \mathrm{WAI}$.
During incubation, responses observed with the application of DGM in soil from Alabata and Osiele were similar to that observed when DCM was applied (Table 2). On the other hand, application of DGM to soil from Itori resulted in optimal release of SOC at $4 \mathrm{WAI}$, though changes in SOC with increasing weeks were not significant in soil from Itori and Papalanto (Table 3). In soil from Papalanto (Table 4), changes in the amount of SOC released with increasing weeks were not significant in the first cycle of 
the screen-house experiment but it reduced significantly with increasing weeks in both soils during the second cycle. The application of GMA to soil from Alabata (Table 2) significantly increased SOC by $98 \%$ at 8 WAI in comparison to 6 WAI. In soil from Osiele, SOC decreased significantly after 4 WAI by $39 \%$ and it increased again by $48 \%$ after 6 WAI. Organic carbon of soil from Itori (Table 3) significantly increased after 0 WAI by $70 \%$ and, thereafter, there was continuous reduction between 2 WAI and 6 WAI, leading to a significant reduction was observed at 6 WAI. However, a decrease in SOC with increasing weeks was observed in soil from Papalanto in the first cycle while SOC decreased with increasing weeks in soil from Alabata and vice versa in soil with Papalanto in the second cycle. A decrease with increasing weeks was observed until 6 WAI after which SOC increased during the field experiment (Table 5).

With the application of DPM, SOC decreased with increasing weeks up to the $6 \mathrm{WAI}$ after which a significant increase was observed in soil from Alabata (Table 2). However, in the second cycle of the screen-house experiment, changes in SOC were erratic but significant. Significantly, higher SOC was recorded at 0 WAI when compared to succeeding weeks in field experiment. Values of SOC after 0 WAI did not change with increasing weeks.

In Table 2, the amount of organic carbon released in soil from Alabata and Osiele at weeks prior 6 WAI did not differ with the incorporation of PMA. SOC decreased significantly at $6 \mathrm{WAI}$ and increased at $8 \mathrm{WAI}$ by 32 and 32\%, respectively, in the soil from Alabata. During screen-house experiment, SOC significantly increased with increasing weeks up to 4 WAI after which a significant decrease was noted at 4 WAI in both soils. In the second cycle of the experiment, SOC changes in soil were significant but not predictable. Changes observed during field experiment (Table 5) were similar to that observed in screen-house experiment.

\section{Effect of amendment on soil ammonium nitrogen}

This study confirms that in the incubation study, $\mathrm{NH}_{4}{ }^{+}-\mathrm{N}$ did not significantly differ as a result of dried manures and manure ashes addition to soil, though increases were noted in Figs. 2 and 3. In Fig. 2, at 0 WAI, $\mathrm{NH}_{4}{ }^{+}-\mathrm{N}$ content of soil from Alabata was highest with the application of PMA (40\% increase) when compared with DCM. The effect of the manure and ash amendment was not significant; however, at 2-8 WAI, ammonium values in the amended soils did not significantly differ from the control soil. Ammonification process in soils amended with dried manures was lower relative to soils amended with manure ashes at 6 and 8 WAI. The conversion of organic nitrogen to ammonium nitrogen was greatly enhanced with application of PMA by $24 \%$ above the control soil at $0 \mathrm{WAI}$ in soil from Osiele. During the first cycle of screen-house experiment, amendment addition led to lower but similar ammonium nitrogen value, then in the control soil at 0 WAI (Fig. 4) values in all amended soil did not differ significantly in soil from Alabata. At the second cycle (Table 6), amendment effect was significant at 4 WAI and 6 WAI. At 4 WAI, significantly lower $\mathrm{NH}_{4}{ }^{+}-\mathrm{N}$ was released from the control soil when compared with CMA, DGM, DPM, and GMA. A significant increase and decrease of 107 and $74 \%$ were observed in soil amended with CMA and PMA compared with their respective dried manures.

\section{Dynamics of soil ammonium nitrogen}

The concentration of ammonium nitrogen in soil changed over the weeks although a non-predictable or erratic pattern of release was recorded with increasing weeks since control, dried manures, manure ash and NPK had different pattern of release (Figs. 2, 3, 4). The highest $\mathrm{NH}_{4}{ }^{+}-\mathrm{N}$ values in soil from Alabata was recorded at 0 WAI for all the amendment except DCM (Fig. 2). $\mathrm{NH}_{4}{ }^{+}-\mathrm{N}$ increased to its peak at 2 WAI and, thereafter, it decreased across the weeks with DCM. As a result of CMA application, $\mathrm{NH}_{4}-\mathrm{N}$ was highest at $0 \mathrm{WAI}$, it reduced at 2 WAI and increased sharply at 4 WAI after which it decreases across the remaining weeks with the decrease being significant at 8 WAI. Similar response was observed with DGM. GMA released significantly higher $\mathrm{NH}_{4}{ }^{+}-\mathrm{N}$ at 0 WAI compared with the other weeks where $\mathrm{NH}_{4}{ }^{+}-\mathrm{N}$ decreases with increasing weeks. This was also similar to the sequence observed with DPM. Poultry manure ash amended soils had the highest $\mathrm{NH}_{4}{ }^{+}-\mathrm{N}$ at $0 \mathrm{WAI}$; it decreased at $2 \mathrm{WAI}$ and increased across the weeks until a decrease occurred at 8 WAI although all the changes motivated by PMA were similar.

Figure 3 shows the ammonium values of soil collected from Itori across the weeks. Generally, for control and amendments except PMA, the highest $\mathrm{NH}_{4}{ }^{+}-\mathrm{N}$ values were released at 0WAI. NPK released lower $\mathrm{NH}_{4}{ }^{+}-\mathrm{N}$ at 2, 4 and 6 WAI, with significantly lower $\mathrm{NH}_{4}{ }^{+}-\mathrm{N}$ at $6 \mathrm{WAI}$ in comparison with 8 WAI. The incorporation of DPM produced the highest $\mathrm{NH}_{4}{ }^{+}-\mathrm{N}$ at 0 WAI with significant decrease at the following weeks. Dried manure of goat reduced $\mathrm{NH}_{4}{ }^{+} \mathrm{N}$ at 2 WAI but increased it at 4 WAI after which $\mathrm{NH}_{4}{ }^{+}-\mathrm{N}$ reduced across the following weeks. Similar response was observed with GMA. $\mathrm{NH}_{4}{ }^{+}-\mathrm{N}$ reduced significantly across the weeks with the application of DCM and similar $\mathrm{NH}_{4}{ }^{+}-\mathrm{N}$ sequence was observed in the control. NPK incorporation to soil from Papalanto reduced $\mathrm{NH}_{4}{ }^{+}-\mathrm{N}$ across the weeks though decrease was only significant at $8 \mathrm{WAI}$ relative to 0 and 2 WAI. DCM released significantly higher $\mathrm{NH}_{4}{ }^{+}-\mathrm{N}$ at 0 WAI when compared with other weeks. Similar response was observed with CMA. GMA increased $\mathrm{NH}_{4}{ }^{+}-\mathrm{N}$ at 6 WAI though erratic pattern was observed at preceding weeks; a significant decrease occurred at 8 WAI relative to 6 WAI. An erratic pattern of $\mathrm{NH}_{4}-\mathrm{N}$ release was also observed with the application of PMA. 
Fig. 2 Changes in ammonium nitrogen of soils from Alabata and Osiele with incubation time
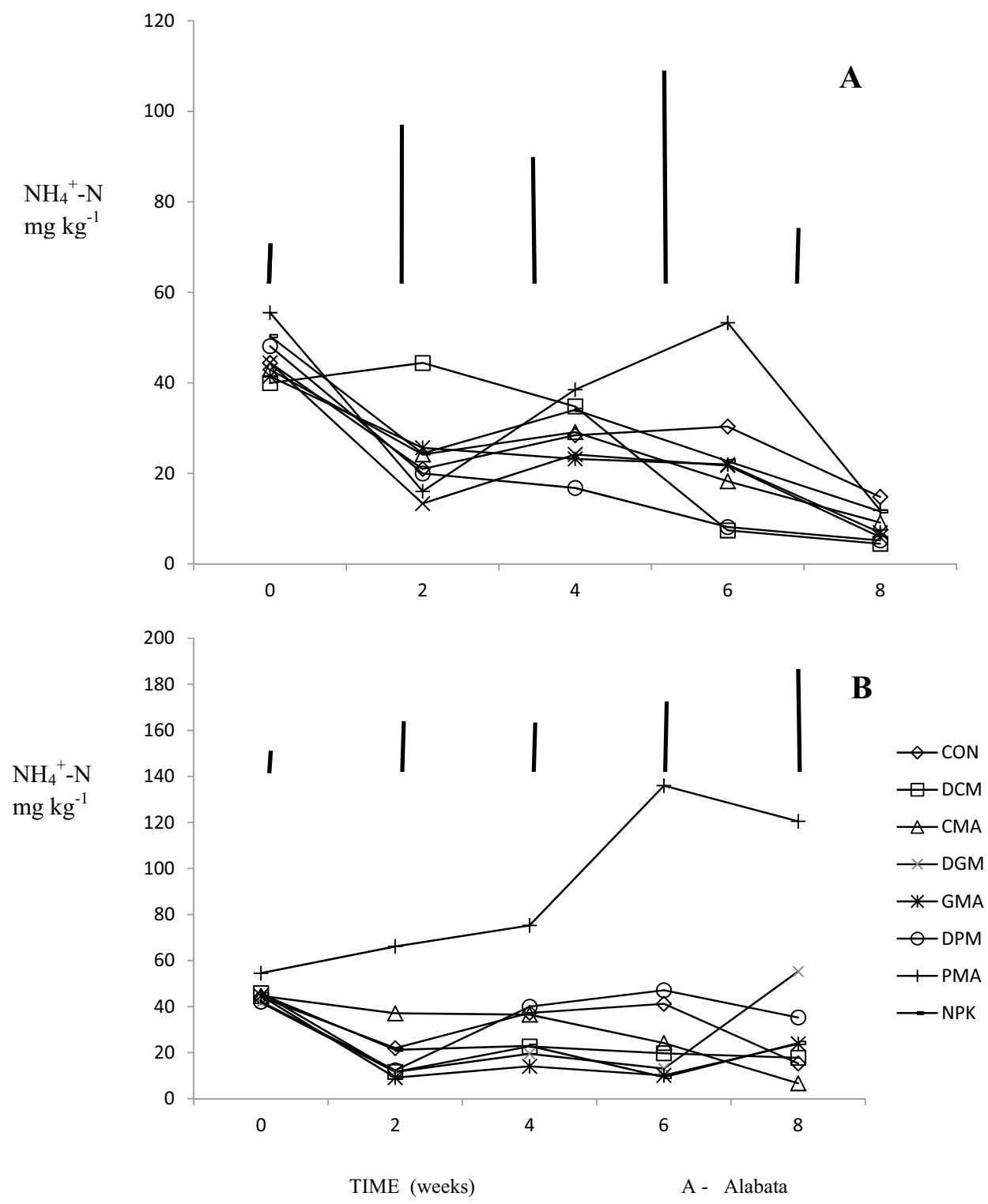

Vertical bars represent least significant difference at $\mathrm{p}<0.05$
Table 6 shows the changes in the ammonium nitrogen of soil from Alabata and Papalanto in the second cycle of the screen-house; DCM increased soil $\mathrm{NH}_{4}{ }^{+}-\mathrm{N}$ across the weeks though significant increase was only recorded at 6 WAI. There was reduction in $\mathrm{NH}_{4}{ }^{+}-\mathrm{N}$ released across the weeks with the application of CMA; meanwhile, $\mathrm{NH}_{4}{ }^{+}-\mathrm{N}$ at 0 WAI was significantly higher than $\mathrm{NH}_{4}{ }^{+}-\mathrm{N}$ at 4 and 6 WAI in soil from Alabata while significant decrease was observed at 6 WAI in Papalanto. Similar response was observed with DGM. The lowest $\mathrm{NH}_{4}{ }^{+}-\mathrm{N}$ was released by PMA at $0 \mathrm{WAI}$, a similar but lower value was obtained at 4 WAI after which a sharp significant increase was observed at 6 WAI. $\mathrm{NH}_{4}{ }^{+}-\mathrm{N}$ increased across the weeks with the application of NPK though the values did not differ significantly.
An erratic pattern of release was observed with the application of PMA and the highest $\mathrm{NH}_{4}{ }^{+}-\mathrm{N}$ was recorded at 0 WAI in the field experiment even though changes across the weeks were not significant (Fig. 8). DPM released significantly higher $\mathrm{NH}_{4}^{+}-\mathrm{N}$ at $8 \mathrm{WAI}$ than $\mathrm{NH}_{4}{ }^{+}-\mathrm{N}$ at 2 and 6 WAI. A non-predictable pattern of release was observed across the weeks with GMA however; a significant increase only occurred at $4 \mathrm{WAI}$ relative to $2 \mathrm{WAI}$.

\section{Effect of amendment on soil nitrate nitrogen}

The study showed that application of manure ashes increased the concentration of nitrate nitrogen in comparison with the control in incubation experiment. Generally, 
Fig. 3 Changes in ammonium nitrogen of soils from Itori and Papalanto with incubation time

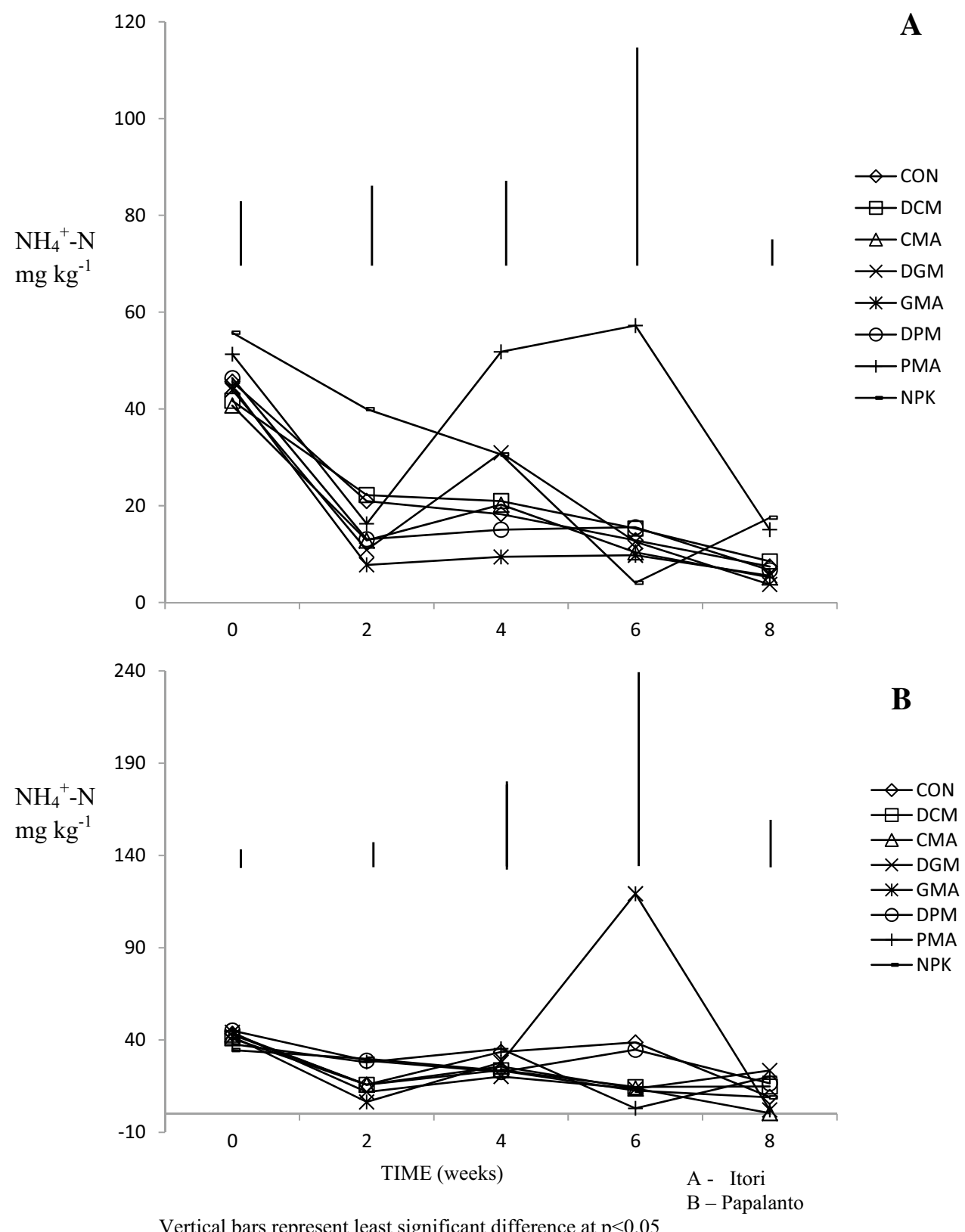

manure ash incorporation led to increases in nitrate nitrogen when compared with their dried manures although some of the increase did not significantly differ (Figs. 5 and 6). In soil collected from Alabata (Fig. 5), application of amendments increased $\mathrm{NO}_{3}-\mathrm{N}$ at $0 \mathrm{WAI}$, a significant increase of $254 \%$ was observed with PMA relative to control. Amendment effect was significant with the application of GMA at 2, 6 and 8 WAI; however, PMA and CMA did not differ from their dried manures but a significant increase in the amount of $\mathrm{NO}_{3}{ }^{-}-\mathrm{N}$ released was observed with GMA relative to DGM. The application of NPK to soil from Papalanto enhanced the release of $\mathrm{NO}_{3}{ }^{-}-\mathrm{N}$ significantly above other amendments. A significant increase of $198 \%$ was observed with NPK when compared to control. At 2 WAI, the highest $\mathrm{NO}_{3}{ }^{-}-\mathrm{N}$ observed in the control did not significantly differ from other amended soil except GMA amended soil. Manure ashes and dried manures except PMA had similar effect on the conversion of ammonium to nitrate at $4 \mathrm{WAI}$ despite that the highest $\mathrm{NO}_{3}{ }^{-}-\mathrm{N}$ observed with PMA was $153 \%$ more than that released in control. The response of soil to amendment at 6 WAI was similar to that observed at 0WAI. At $8 \mathrm{WAI}$, amendment did not differ except with NPK and DCM. In field experiment, application of poultry manure ash encouraged significantly higher $\mathrm{NO}_{3}{ }^{-}-\mathrm{N}$ at $335 \%$ over the control soil at 0 WAI as shown in Fig. 8. Manure ash increased $\mathrm{NO}_{3}{ }^{-}-\mathrm{N}$ 
Fig. 4 Changes in soil ammonium nitrogen in screen-house (cycle 1)

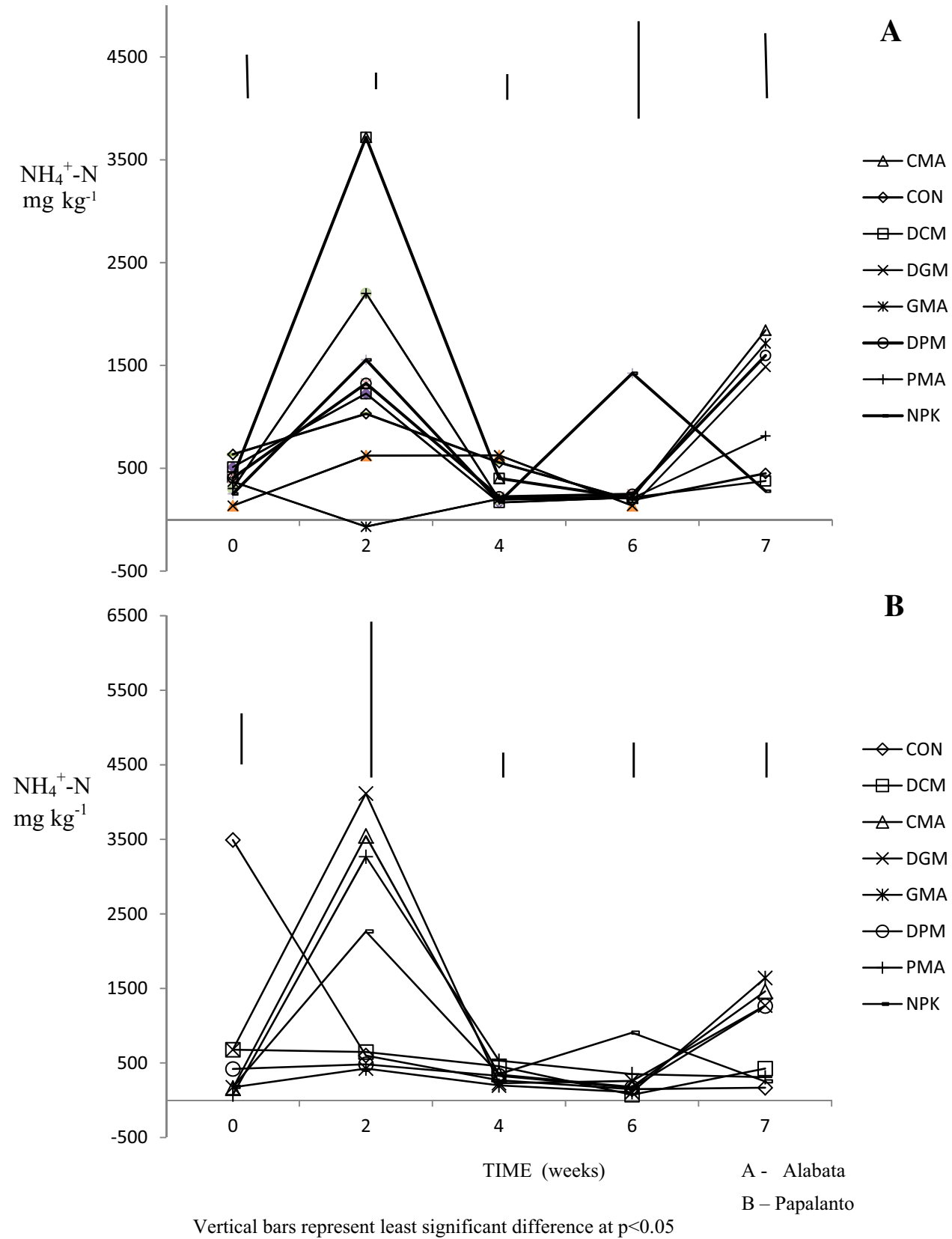


Table 6 Effect of amendments and time on Soil ammonium nitrogen and nitrate nitrogen of Alabata and Papalanto in screen-house (cycle 2)

\begin{tabular}{|c|c|c|c|c|c|c|c|c|}
\hline Treatment & $\begin{array}{l}\mathrm{NH}_{4}^{+}-\mathrm{N} \\
0 \mathrm{WAI}\end{array}$ & $\begin{array}{l}\left(\mathrm{mg} \mathrm{kg}^{-1}\right) \\
4 \mathrm{WAI}\end{array}$ & $6 \mathrm{WAI}$ & $\mathrm{Lsd}^{*}$ & $\begin{array}{l}\mathrm{NO}_{3}{ }^{-}-\mathrm{N} \\
0 \mathrm{WAI}\end{array}$ & 4 WAI & $\begin{array}{l}\left(\mathrm{mg} \mathrm{kg}^{-1}\right) \\
6 \text { WAI }\end{array}$ & $\operatorname{Lsd}^{* *}$ \\
\hline \multicolumn{9}{|l|}{ Alabata } \\
\hline Control & $450.2 b$ & $315.8 \mathrm{c}$ & $460.2 b$ & 97.99 & $55.44 \mathrm{c}$ & $209.56 \mathrm{a}$ & $182.34 \mathrm{a}$ & 97.9 \\
\hline Dried cattle manure & $376.2 b$ & $592.0 \mathrm{bc}$ & $3223.7 \mathrm{a}$ & 218.94 & $133.89 \mathrm{a}$ & $269.86 \mathrm{a}$ & $249.46 \mathrm{a}$ & 218.9 \\
\hline Cattle manure ash & $1843.8 \mathrm{a}$ & $1227.2 \mathrm{a}$ & $653.7 \mathrm{~b}$ & 54.13 & $73.94 b c$ & $151.83 \mathrm{a}$ & $218.02 \mathrm{a}$ & 54.13 \\
\hline Dried goat manure & $1486.2 \mathrm{a}$ & $721.5 \mathrm{a}$ & $691.5 b$ & 397.38 & $114.50 \mathrm{ab}$ & $232.23 \mathrm{a}$ & $230.44 a$ & 397.3 \\
\hline Goat manure ash & $1714.3 \mathrm{a}$ & $1110.3 \mathrm{abc}$ & $1147.0 \mathrm{~b}$ & 165.44 & $126.71 \mathrm{ab}$ & $199.93 \mathrm{a}$ & $228.64 a$ & 165.4 \\
\hline Dried poultry manure & $1597.2 \mathrm{a}$ & $1275.7 \mathrm{a}$ & $783.2 \mathrm{~b}$ & 270.76 & $53.16 \mathrm{c}$ & $280.69 a$ & $141.78 \mathrm{a}$ & 270.7 \\
\hline Poultry manure ash & $481.2 b$ & $320.7 \mathrm{c}$ & $789.3 b$ & 72.08 & $98.54 \mathrm{abc}$ & $171.22 \mathrm{a}$ & $101.58 \mathrm{a}$ & 72.08 \\
\hline NPK (15-15-15) & $277.5 b$ & $992.8 \mathrm{ab}$ & $1159.3 b$ & 87.16 & $79.33 b c$ & $175.16 \mathrm{a}$ & $75.52 \mathrm{a}$ & 87.16 \\
\hline \multicolumn{9}{|l|}{ Papalanto } \\
\hline Control & $167.2 \mathrm{~b}$ & $363.3 \mathrm{c}$ & $953.7 \mathrm{bcd}$ & 362.46 & $90.41 \mathrm{a}$ & $136.04 \mathrm{bc}$ & $232.95 b$ & 91.28 \\
\hline Dried cattle manure & $274.5 b$ & $2336.7 \mathrm{a}$ & $388.0 \mathrm{~d}$ & 665.11 & $55.93 \mathrm{a}$ & $502.15 \mathrm{a}$ & $181.10 \mathrm{bc}$ & 100.1 \\
\hline Cattle manure ash & $1461.5 \mathrm{a}$ & $1319.5 b$ & $666.8 \mathrm{~cd}$ & 459.62 & $56.75 \mathrm{a}$ & $190.96 \mathrm{~b}$ & $226.85 b$ & 114.2 \\
\hline Dried goat manure & $1270.3 \mathrm{a}$ & $777.0 \mathrm{bc}$ & $1523.0 \mathrm{~b}$ & 447.46 & $56.60 \mathrm{a}$ & $199.93 b$ & $234.66 \mathrm{~b}$ & 179.8 \\
\hline Goat manure ash & $1640.3 \mathrm{a}$ & $949.7 b c$ & $3213.8 \mathrm{a}$ & 1494.1 & $84.35 \mathrm{a}$ & $83.28 \mathrm{c}$ & $382.68 \mathrm{a}$ & 142.2 \\
\hline Dried poultry manure & $1264.2 \mathrm{a}$ & $458.3 \mathrm{bc}$ & $1288.0 \mathrm{bc}$ & 241.82 & $61.38 \mathrm{a}$ & $119.17 \mathrm{bc}$ & $192.03 b c$ & 95.3 \\
\hline Poultry manure ash & $308.3 b$ & $2226.8 \mathrm{a}$ & $548.8 \mathrm{~d}$ & 1890.8 & $51.73 \mathrm{a}$ & $62.46 \mathrm{c}$ & $150.76 \mathrm{bc}$ & 71.45 \\
\hline NPK (15-15-15) & $252.8 \mathrm{~b}$ & $289.8 \mathrm{c}$ & $2646.3 \mathrm{a}$ & 740.5 & $41.64 \mathrm{a}$ & $118.85 b c$ & $119.21 \mathrm{c}$ & 57.00 \\
\hline
\end{tabular}

Means with the same letter(s) within the same column are significantly different at $p<0.05$

WAI Weeks after incorporation

*Lsd across the weeks for ammonium nitrogen across the weeks

**Lsd across the weeks for nitrate nitrogen across the weeks

the highest $\mathrm{NO}_{3}-\mathrm{N}$ at $0 \mathrm{WAI}$ after which $\mathrm{NO}_{3}{ }^{-}-\mathrm{N}$ decreased across the weeks in soil from Alabata. Application of GMA significantly increased $\mathrm{NO}_{3}{ }^{-}-\mathrm{N}$ across the weeks with the highest significant increase at 8 WAI in both soils. For PMA, $\mathrm{NO}_{3}{ }^{-}-\mathrm{N}$ at 0 and 8 WAI did not differ until after 6 WAI, where significantly higher $\mathrm{NO}_{3}{ }^{-}-\mathrm{N}$ was released in both soils despite that there was a decrease after 0 WAI. $\mathrm{NO}_{3}{ }^{-}-\mathrm{N}$ was similar across the weeks in control soil from Itori although the highest $\mathrm{NO}_{3}{ }^{-}-\mathrm{N}$ was observed at 8WAI as presented in Fig. 6. For all the amendments, the highest $\mathrm{NO}_{3}{ }^{-}-\mathrm{N}$ was released at $8 \mathrm{WAI} . \mathrm{NO}_{3}{ }^{-}-\mathrm{N}$ was lowest at 0 WAI and increased with increasing weeks for GMA and DPM. $\mathrm{NO}_{3}{ }^{-}-\mathrm{N}$ reduced at 2 WAI for PMA and NPK after which subsequent increase was recorded up to 8 WAI. The lowest $\mathrm{NO}_{3}{ }^{-}-\mathrm{N}$ was at 0 WAI for DCM, CMA, and DGM, only that DCM decreased $\mathrm{NO}_{3}{ }^{-}-\mathrm{N}$ at 2 WAI with increases in subsequent weeks. For $\mathrm{CMA}, \mathrm{NO}_{3}{ }^{-} \mathrm{N}$ decreased at 2 $\mathrm{WAI}$, increased at $4 \mathrm{WAI}$, decreased again at $6 \mathrm{WAI}$ and finally increased significantly at 8 WAI. A non-predictable pattern was observed with DGM across the weeks with a final considerable increase at 8 WAI.

In the screen-house experiment (Fig. 7), Application of DCM led to increase in $\mathrm{NO}_{3}{ }^{-}-\mathrm{N}$ up to 2 WAI after this $\mathrm{NO}_{3}{ }^{-}-\mathrm{N}$ decreased till 6 WAI. The lowest $\mathrm{NO}_{3}{ }^{-}-\mathrm{N}$ was recorded at 0 WAI with CMA, a significant increase occurred at 2 WAI and after $4 \mathrm{WAI}, \mathrm{NO}_{3}{ }^{-}-\mathrm{N}$ decreased across the weeks. Similar response was observed with DGM. Significantly higher $\mathrm{NO}_{3}{ }^{-}-\mathrm{N}$ was recorded at 4 WAI when compared with $\mathrm{NO}_{3}{ }^{-}-\mathrm{N}$ at preceeding and succeeding weeks with the application of GMA. A decrease in $\mathrm{NO}_{3}{ }^{-}-\mathrm{N}$ released across weeks was observed with the application of DPM as the highest $\mathrm{NO}_{3}{ }^{-}-\mathrm{N}$ was produced at 0 WAI. In the second cycle of screen-house experiment (Table 6), soil from Alabata had the highest release of nitrate nitrogen at 4WAI; however, the incorporation of CMA allowed significant increase in $\mathrm{NO}_{3}{ }^{-}-\mathrm{N}$ across the weeks. The amount of $\mathrm{NO}_{3}{ }^{-}-\mathrm{N}$ released with PMA increased significantly at 4 WAI in comparison with 0 WAI while a considerable decrease occurred at 6 WAI. In soil collected from Papalanto, $\mathrm{NO}_{3}-\mathrm{N}$ was lowest at $0 \mathrm{WAI}$, with the application of DCM it increased significantly at 4 WAI after which an abrupt reduction was observed at 6 WAI. A decline was recorded in $\mathrm{NO}_{3}{ }^{-}-\mathrm{N}$ from 0 to $4 \mathrm{WAI}$, an abrupt significant increase occurred at 6 WAI with GMA. DPM encouraged significant increase in $\mathrm{NO}_{3}{ }^{-}-\mathrm{N}$ with increasing weeks. Nitrate nitrogen increased across the weeks as a result of PMA addition though increase was significant only at 6 WAI. 
Fig. 5 Changes in nitrate nitrogen of soils from Alabata and Osiele with incubation time
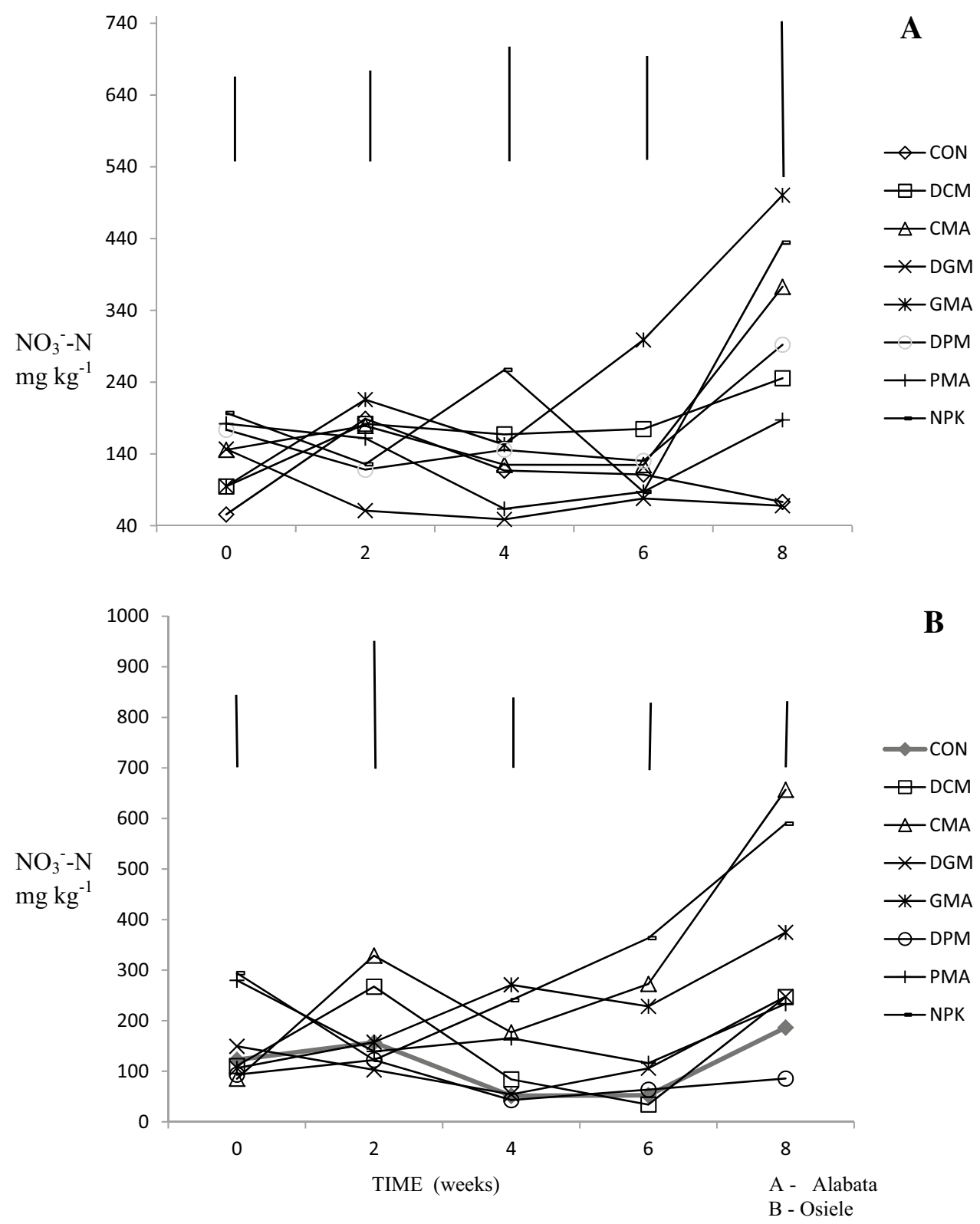

Vertical bars represent least significant difference at $\mathrm{p}<0.05$
The pattern of soil nitrate nitrogen during field experiment is shown in Fig. 8. In the control soil, $\mathrm{NO}_{3}{ }^{-} \mathrm{N}$ was significantly lower at 0 and $4 \mathrm{WAI}, \mathrm{NO}_{3}{ }^{-}-\mathrm{N}$ increased significantly across the weeks with the highest at 8 WAI. DCM application produced a considerable increase in $\mathrm{NO}_{3}{ }^{-}-\mathrm{N}$ at 2 WAI after which it decreased across the weeks. There was no significant difference in $\mathrm{NO}_{3}{ }^{-}-\mathrm{N}$ released by CMA across the weeks but the highest value was at 8 WAI. DGM significantly increased $\mathrm{NO}_{3}{ }^{-}-\mathrm{N}$ at 2 WAI in comparison to other weeks. Similar response was observed with NPK. There was no significant difference in $\mathrm{NO}_{3}{ }^{-}-\mathrm{N}$ at 0 to 8 WAI with PMA; the highest and lowest $\mathrm{NO}_{3}{ }^{-}-\mathrm{N}$ was observed at 8 and $10 \mathrm{WAI}$, respectively.

\section{Discussion}

The experimental soils were slightly acidic to slightly alkaline in $\mathrm{pH}$ and the highest $\mathrm{pH}$ value in soil from Itori could be due to its proximity to Ewekoro cement company and the consequent pollution with calcium dust (Azeez 2004). Incineration of manure increased the $\mathrm{pH}$, 
Fig. 6 Changes in nitrate nitrogen of soils from Itori and Papalanto with incubation time

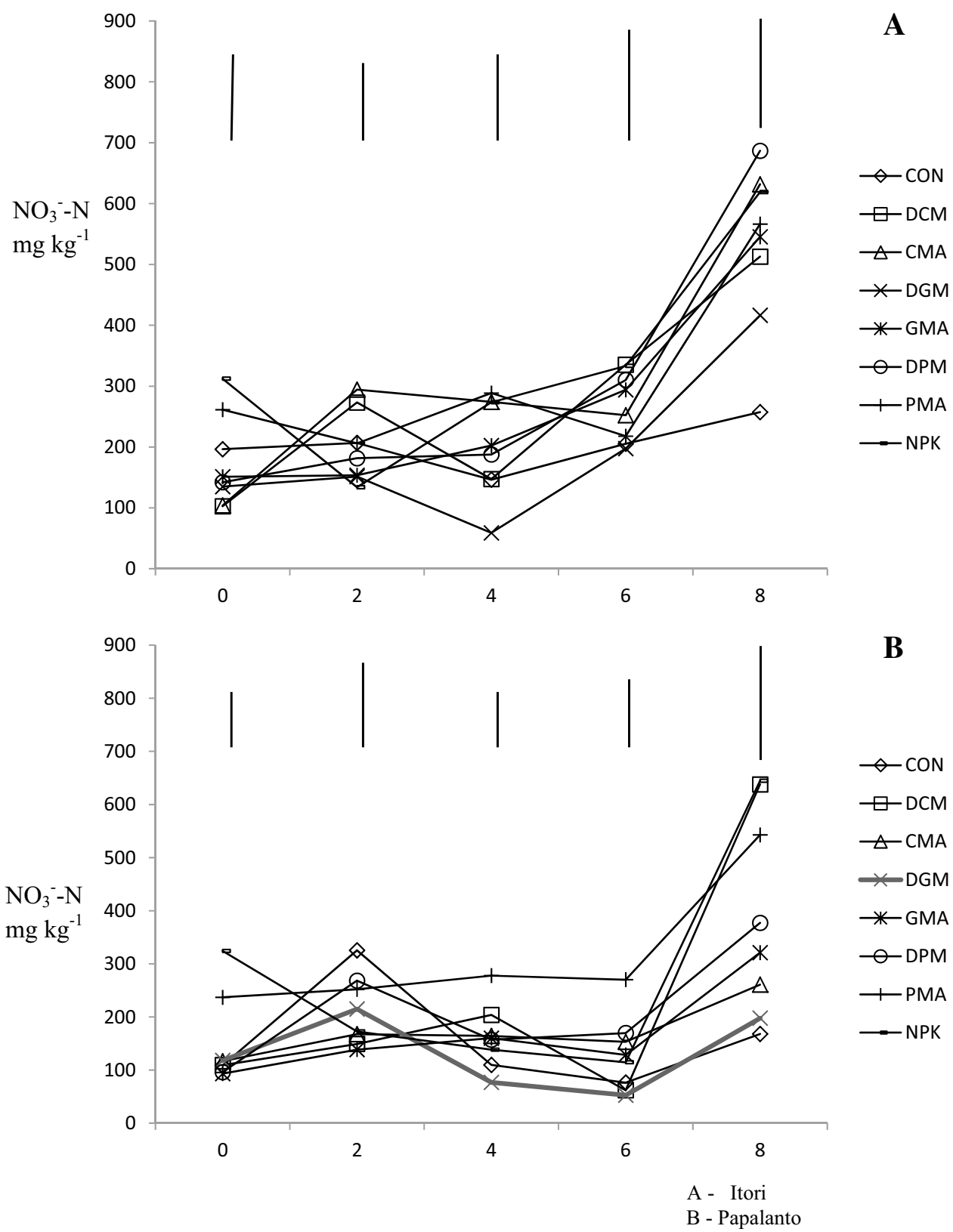

Vertical bars represent least significant difference at $\mathrm{p}<0.05$ exchangeable cations, and carbon-nitrogen ratio. This is due to the burning off the non-nutrient part of the manure and the concentration of the nutrients in the manure when ashed. This supports the findings of Lal and Ghuman (1989) that the conversion of biomass to ash increased the levels of cations and other nutrient element. The $\mathrm{pH}$ of dried manures was strongly alkaline, while that of manure ashes was considered very strongly alkaline. This would enable mineralization and release of nutrients when they are applied to soil. Significantly, higher $\mathrm{pH}$ was observed in manure ashes in comparison to their dried manures as this could be attributed to the concentration of basic cations that contributed to increasing soil $\mathrm{pH}$.

Exchangeable cations were medium to high in the soils. The total organic carbon of the soils was observed to be very high. Even though the total nitrogen content of the soils were very high, this may not necessarily signify a high content of available nitrogen for plant uptake, especially if the organic $\mathrm{N}$ content of such soils is high. Soils from Alabata, Osiele, Itori and FUNAAB were loamy sand, while soil from Papalanto was sand (USDA 2010). There was a significant increase in calcium, magnesium, potassium and sodium content of manures after ashing. GMA is richer in sodium 
Fig. 7 Changes in soil nitrate nitrogen in screen-house (cycle 1)

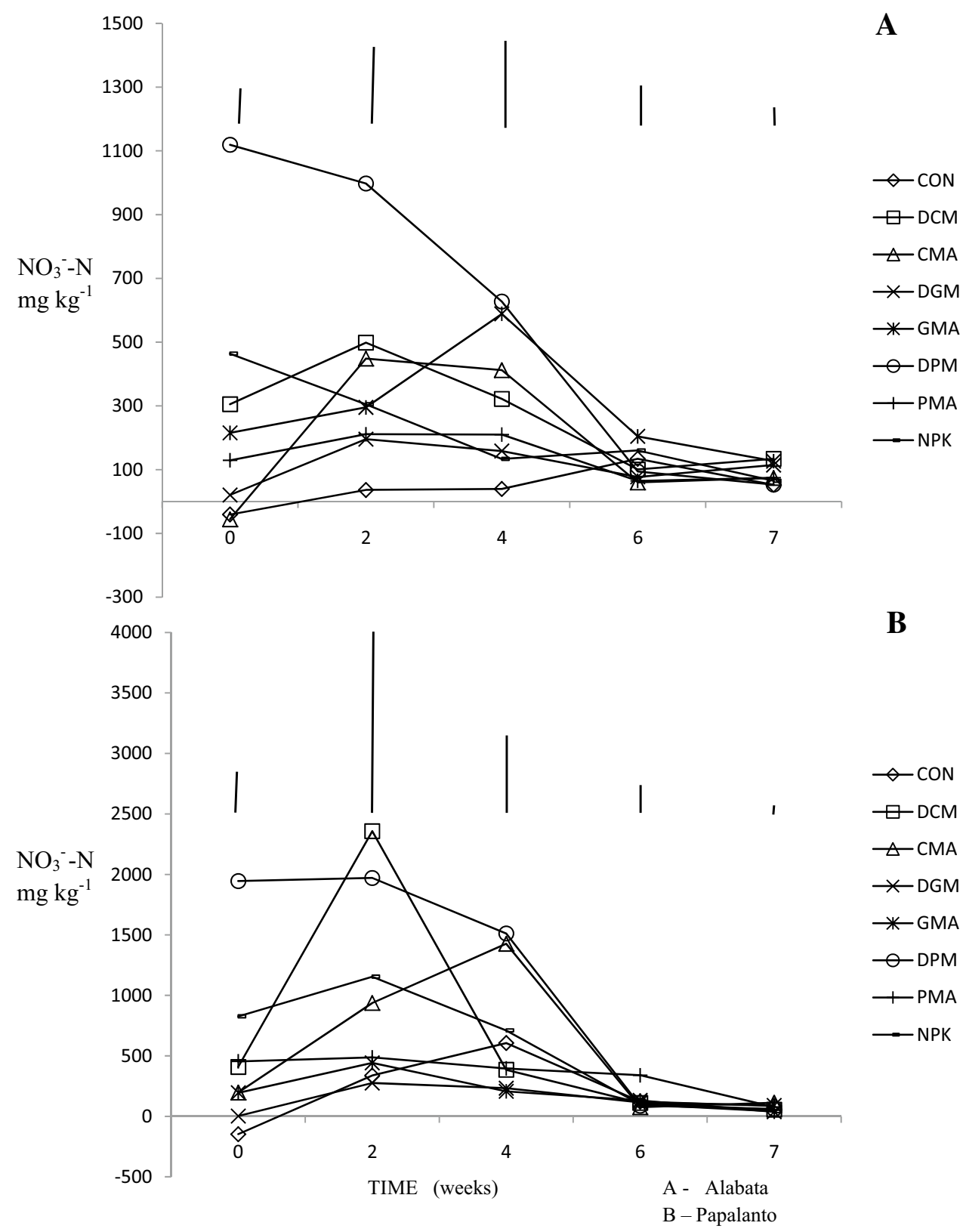

Vertical bars represent least significant difference at $\mathrm{p}<0.05$ and potassium when compared to cattle and poultry manure ash. This supports the findings of Azeez and Van Averbeke (2010) that abundance of manure $\mathrm{K}$ is in the order of goat manure $>$ poultry manure $>$ cattle manure. However, poultry manure ash is richer than goat manure ash and cattle manure in terms of calcium and magnesium contents. This is as a result of calcium and magnesium salts that are specifically added to poultry diets for egg production (layers).

No significant reduction in total organic carbon and nitrogen of manures after burning at $320-450{ }^{\circ} \mathrm{C}$. The total nitrogen of manures did not significantly differ from that of manure ash; this shows that incineration of manure at this temperature did not lead to significant loss of nitrogen. This is in disagreement with the findings of Teppei et al. (2012) that $\mathrm{C}$ and $\mathrm{N}$ contained as organic compounds were incinerated and gasified as nitrogen and carbon dioxide. The nonconformity of this result to the results of Teppei et al. (2012) could be attributed to the difference in temperature of ashing since the dried or composted manures were incinerated at $700{ }^{\circ} \mathrm{C}$ in Teppei et al. (2012). The highest total nitrogen of dried poultry manure reported in this study is in conformity with Azeez and Van Averbeke (2010). The carbon-nitrogen ratio follows the order of goat manure ash $>$ cattle manure ash $>$ dried goat manure $>$ dried cattle manure $>$ dried poultry manure = poultry manure ash (data not shown). This implies that dried poultry manure and its ash is expected to 
Fig. 8 Changes in soil ammonium nitrogen and nitrate nitrogen in field evaluation

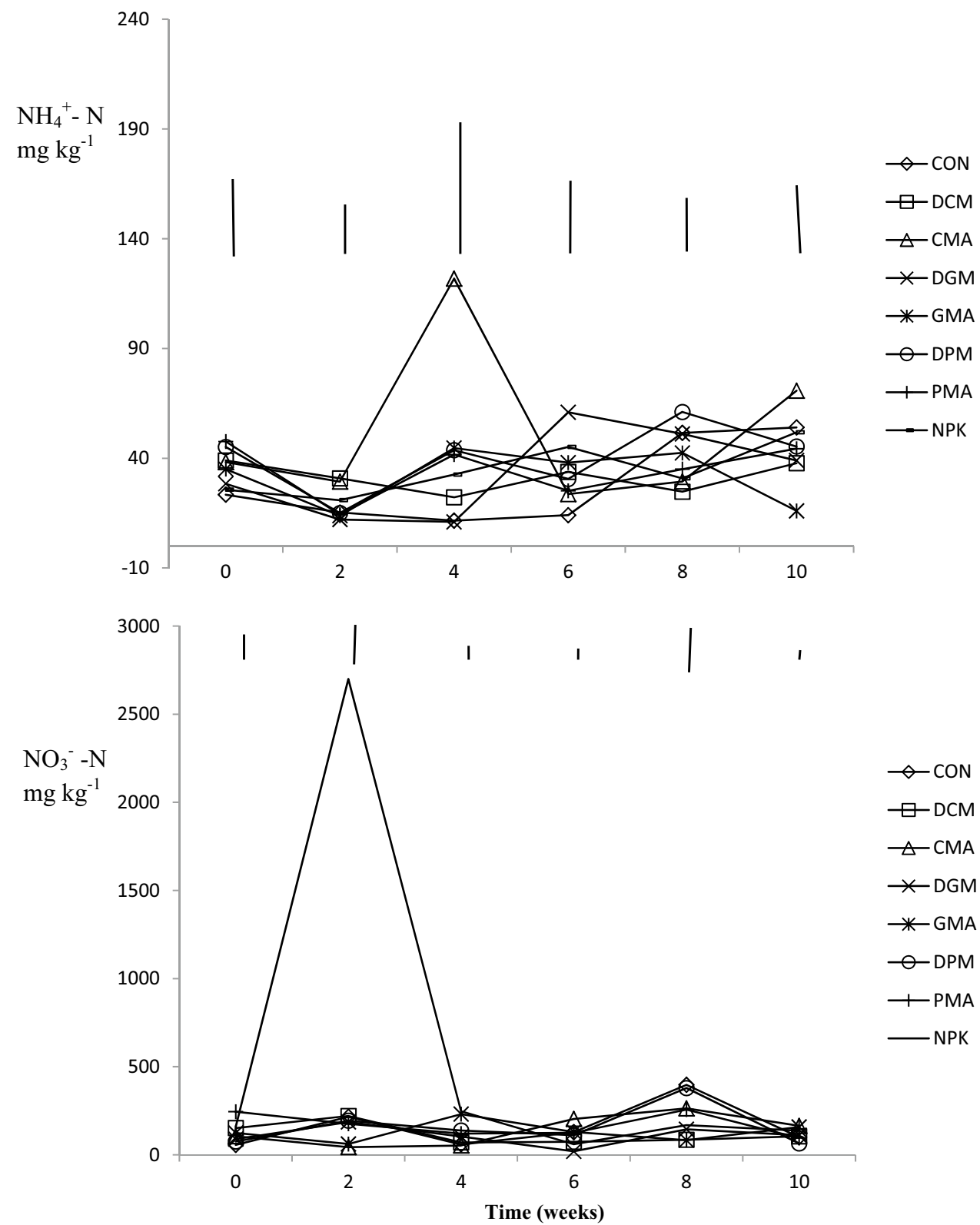

Vertical bars represent least significant difference at $\mathrm{p}<0.05$ mineralize faster than other ashes; nutrients will be released rapidly from dried poultry manure when compared with dried manures of goat and cattle. This supports the findings of Qiu et al. (2008) that poultry manure is expected to mineralize faster than cattle manure and least in goat manure. However, immobilization of nutrients is likely to occur in goat and cattle manures.

Incorporation of amendments to soil increases the soil organic matter with a major component as organic carbon. Generally, amended soils recorded higher organic carbon when compared with the control soil. This conforms to the result of Ojeniyi (2000) who reported that increase in the level of soil organic carbon and organic matter was expected since organic manures have the ability of increasing soil organic matter content. It has also been reported that the contents of some major nutrients in the soil were slightly dependable on the level of organic matter (Adeniyan and Ojeniyi 2005). Amendment effect on soil organic carbon was environment and soil type dependent according to the findings of this study. This is because the effect of manures and manure ashes was different relative to the type of environment; controlled environment (incubation and screen-house) and non-controlled environment (field). In the field experiment, only manure ash of poultry differed from its dried manure, the similarities between DGM, DCM and their ashes could be attributed 
to similar organic carbon content in these amendments allowing them to behave the same way in the field experiment. Dried manures and manure ash did not have residual effect since amendment effect was not significant at the second cycle of the experiment. The abrupt increase in the SOC after incorporation of NPK could be attributed to mineralization processes in the soils due to their native fertility and the presence of microbes.

Organic carbon was least released from the amendments at $6 \mathrm{WAI}$ while at $4 \mathrm{WAI}$ more of it was released in most of the amendment. The probable reason for the high release of organic carbon at 4 WAI may be attributed to increase mineralization of organic matter at $4 \mathrm{WAI}$, thereby increasing $\mathrm{SOC}$, which is a major component of organic matter. The inconsistency in dynamics of SOC may be due to the usage of organic carbon by microbial community as energy and food sources at the first week, thereby decreasing it at the succeeding weeks. In a similar study, it was reported that the proliferation of microbial population leads to competition and death of microbes; this was adduced as the major reason as for inconsistency in organic carbon changes with time (Azeez and Van Averbeke 2010). The higher content of organic carbon release at 0 WAI may be because of enhanced organic manure and manure ash mineralization at the onset of incorporation. This is similar to the findings of (Sajal and Abul Kashem 2014) who reported that the highest amount of soil organic carbon at the beginning of incubation experiment was indicative of a larger pool of the less resistant fractions that were available to be broken down and recycled, thus, resulting in lower contents remaining at the end incubation. Mannivannan et al. (2009) and Gulser et al. (2010) also found that the addition of organic residues increases the soil organic carbon level initially and with the course of time organic carbon content decreases in soil up to a certain period.

This study confirms that in the incubation study, $\mathrm{NH}_{4}{ }^{+}-\mathrm{N}$ did not significantly differ as a result of dried manures and ashes addition to soil despite that increases were observed; this signifies that ammonification process is controlled not only by the characteristics of added material but also by the soil environmental condition including the microbial community. The rapid conversion of ammonium to nitrate through nitrification process could also be the rationale for the similar ammonium content of dried manure amended soil and ash amended soil. Additionally, it could also be because nutrients in the manure had not been equilibrated with the soil. Azeez and Van Averbeke (2010) reported that ammonium mineralized by the manures could be trapped by soil constituents or temporarily immobilized by soil microorganism, or further transformed into nitrate or lost as ammonia under favorable soil conditions. The increase in $\mathrm{NH}_{4}{ }^{+}-\mathrm{N}$ of amended soils is in line with the findings of Sajal and Abul Kashem (2014) that the application of organic manures produced higher amount of available $\mathrm{NH}_{4}{ }^{+}-\mathrm{N}$ in amended soils compared to control soil. Poultry manure ash had the smallest carbon:nitrogen ratio which enhanced mineralization process when compared to other amendments; this could have been the rationale for its ability to release higher $\mathrm{NH}_{4}{ }^{+}-\mathrm{N}$ than other amendments.

The concentration of ammonium nitrogen in soil changed over the weeks although a non-predictable or erratic pattern of release was recorded with increasing weeks since control, dried manures, manure ash and NPK had different pattern of releasing ammonium. The increase at $0 \mathrm{WAI}$ and subsequent decrease was similar to the findings of Duffera et al. (1999) who observed that the processed swine lagoon solids increased the concentrations of ammonium nitrogen and during the first week and by the second to fourth week after application, the ammonium nitrogen concentrations dropped. The increase in soil ammonium with the application of PMA after 2 WAI could be because poultry manure ash had most of its nitrogen in ammonium form and its lower $\mathrm{C}: \mathrm{N}$ could have enhanced ammonification process after 2 WAI. David et al. (2009) reported the increase in ammonium content during the onset of composting period in which it is biologically transformed into $\mathrm{NO}_{3}-\mathrm{N} / \mathrm{NO}_{2}-\mathrm{N}$ via nitrification. This study confirms that in screen-house experiment, ammonification process was higher than nitrification process since more ammonium nitrogen than nitrate nitrogen was recorded across the weeks. Uptake of available nitrogen by plant or immobilization of nitrate could be the reason for the lower nitrate nitrogen content in amended soils during screen-house experiment.

The findings in this study conform to Abassi et al. (2007) who reported that soil amended with organic manures accumulated significantly more nitrate than soil without organic manures. Biological process like immobilization in which microbial community use part of the available nitrate as energy source during the mineralization could be the reason for the non-significance in the nitrate nitrogen of soil amended with ash relative to soil amended with dried manures. The significant increase in $\mathrm{NO}_{3}{ }^{-}-\mathrm{N}$ under field condition may be attributed to the fact that NPK contained the available form of nitrogen as $\mathrm{NO}_{3}{ }^{-}-\mathrm{N}$ and the sharp increase at 2 WAI was because it was incorporated at 2 WAI. The low $\mathrm{NO}_{3}{ }^{-}-\mathrm{N}$ stimulated by NPK at subsequent weeks after could be attributed to leaching or uptake of available nitrogen. This is supported with the findings of Adeniyan et al. (2011) who reported that the nutrients released from NPK fertilizer were for a short period because leaching of nutrients may be higher in the soil treated with NPK fertilizer than the soil treated with organic manures.

In incubation study, nitrate nitrogen increased across the weeks for most of the amendments. Nitrification process was optimum at 8 WAI for all amendment and control while nitrification was lower at 0 WAI. Although in soil 
from Alabata and Itori, immobilization occurred at 4 WAI with the application of PMA and DGM while in soil from Osiele and Papalanto, immobilization occurred at 6WAI with the application of DCM and PMA. Changes in nitrate observed across the weeks were erratic in screen-house and field experiment; however, during screen-house experiment, the least amount of nitrate was released at the end of the experiment in both soils due to nitrogen losses either through immobilization or uptake.

\section{Conclusion}

Dried manures and manure ashes differ in their characteristics; incineration of dried manures led to increase in $\mathrm{pH}$ and concentration of nutrients especially exchangeable cations. Dried manures and manure ashes are comparable in terms of total organic carbon and total nitrogen content. Generally, the addition of amendment increased soil organic carbon, the effect of dried manures and manure ash on soil organic carbon is environment dependent, and the addition of amendment did not have residual effect on soil organic carbon. Ammonification and nitrification process was increased with the application of manure ash, especially PMA and the conversion of organic nitrogen to ammonium nitrogen is not only controlled by the characteristics of added material but also by the soil environmental condition. The release of nitrogen through nitrification process depends on the type of soil and amendment. Soil organic carbon and nitrogen availability release indices were not consistent with increasing time hence erratic. Nitrification is more pronounced under incubation and field conditions than ammonification process and vice versa was observed in screen-house experiment.

Acknowledgements The authors wish to acknowledge soils of Forest Island in Africa (SOFIIA-FUNAAB) for its support in laboratory analyses. SOFIIA is a collaborative research project funded through the UK Government's Royal Society-DFID Africa Capacity Building Initiative. Opinions expressed and conclusions arrived at are those of the authors and are not necessarily to be attributed to the project.

Open Access This article is distributed under the terms of the Creative Commons Attribution 4.0 International License (http://creativeco mmons.org/licenses/by/4.0/), which permits unrestricted use, distribution, and reproduction in any medium, provided you give appropriate credit to the original author(s) and the source, provide a link to the Creative Commons license, and indicate if changes were made.

\section{References}

Abassi MK, Hina M, Khalique A, Khan SR (2007) Mineralization of three organic manures used as nitrogen source in a soil incubated under laboratory conditions. Commun Soil Sci Plant Anal 38:1691-1711. https://doi.org/10.1080/00103620701435464

Adeniyan ON, Ojeniyi SO (2005) Effect of poultry manure and NPK 15-15-15 and combination of their reduced levels on maize growth and soil chemical properties. Niger J Soil Sci 15:34-41

Adeniyan ON, Ojo AO, Akinbode OA, Adediran JA (2011) Comparative study of different organic manures and NPK fertilizer for improvement of soil chemical properties and dry matter yield of maize in two different soils. J Soil Sci Environ Manag 2(1):9-13

Adetunji MT (1991) An evaluation of the soil nutrient status for maize production in South Western Nigeria. J Agric Res 8:101-113

Ayeni LS, Adetunji MT, Ojeniyi SO, Ewulo BS, Adeyemo AJ (2008) Comparative and cumulative effect of cocoa pod husk ash and poultry manure on soil and maize nutrient contents and yield. Am Eurasian J Sustain Agric 2(1):92-97

Azeez JO, Adetunji MT (2004) Comparative effects of organic and inorganic fertilizer on soil chemical properties: an incubation experiment. Proceedings of the 29th annual conference of the Soil Science Society of Nigeria. Dec 6-10 pp 198-205

Azeez JO, Van Averbeke W (2010) Nitrogen mineralization potential of three animal manures applied on a sandy clay loam soil. Biores Technol 101:5645-5651. https://doi.org/10.1016/j.biort ech.2010.01.119

Baker KF (1976) The determination of organic carbon in soil using a probe colorimeter. Lab Pract 25:82-83

Bouyoucos GH (1965) A calibration of the hydrometer method for testing mechanical analysis of soils. Agric J 43:434-438

Cataldo DA, Haroon M, Schrander LE, Youngs VL (1975) Rapid colorimeteric determination of nitrate in plant tissue by nitration of salicylic acid. Commun Soil Sci Plant Anal 6:71-80. https://doi. org/10.1080/00103627509366547

Chadwick DR, John F, Pain BF, Chambers BJ, Williams JC (2000) Plant uptake of nitrogen from the organic nitrogen fraction of animal manures: a laboratory experiment. J Agric Sci Camb 134:159-168. https://doi.org/10.1017/s0021859699007510

David FW, Steven KM, Thomas LR, Heekwon A (2009) Effects of a livestock manure windrow composting site with a fly ash pad surface and vegetative filter strip buffers on sediment, nitrate, and phosphorus losses with runoff. Agric Eng publ. pp 1-10 http://lib.dr.iastate.edu/cgi/viewcontent.cgi?article=1229\&conte $\mathrm{xt}=$ abe_eng_pubs

Duffera M, Robarge WP, Mikkelsen RL (1999) Estimating the Availability of nutrients from processed swine lagoon solids through incubation studies. Bio Technol 70:261-268. https://doi. org/10.1016/s0960-8524(99)00039-5

Edmeades DC (2003) The long-term effects of manures and fertilizers on soil productivity and quality. Nutr Cycl Agroecosyst 66:165-180

Griffin E, Hoyle FC, Murphy DV (2013) Soil organic carbon. In report card on sustainable natural resource use in agriculture. Department of Agriculture and Food, South Perth, Western Australia. Accessed online 20Oct 2017

Gulser C, Demir Z, Ic S (2010) Changes in some soil properties at different incubation periods after tobacco waste application. $\mathbf{J}$ Environ Bio 31:671-674

Hao X, Godlinski F, Chang C (2008) Distribution of phosphorus forms in soil following long-term continuous and discontinuous cattle manure applications. Soil Sci Soc Am J 72:90-97. https://doi. org/10.2136/sssaj2006.0344

Hossain MA, Hamid A, Nasreen S (2007) Effect of nitrogen and phosphorus fertilizer on N/P uptake and yield performance of groundnut (Arachis hypogaea L). J Agric Res 45:119-127

Kaira YP, Maynard DG (1991) Method manual for forest soil and plant analysis. Information Report NOR-X-319. Forestry Canada, Northwest Region, Northern Forestry Centre, Edmonton, Alberta. http://web.unbc.ca/ arocenaj/lab/kalra_maynard.pdf 
Ksawery K, Robert JB, Tjalfe GP, Baiq EY (2012) Ash from the thermal gasification of pig manure-effects on ryegrass yield, element uptake, and soil properties. Soil Res 50:406-415. https:// doi.org/10.1071/SR12075

Lal R, Ghuman BS (1989) Biomass burning in windows after clearing a tropical rain forest: effect on soil properties, evaporation and crop yields. Field Crop Res 22(4):247-255. https://doi. org/10.1016/0378-4290(89)90025-7

Law-Ogbomo KE, Egharevba RKA, Osaigbovo AU (2011) The effect of poultry manure on growth and yield of Amaranthus cruentus and properties. Benson Idahosa University Nigeria, book of abstract of the 29th annual national conference of Horticultural Society of Nigeria 24th-29th July, University of Makurdi Nigeria. p 59

Mannivannan S, Balamurugan M, Parthasarathi K, Gunasekaran G, Ranganathan LS (2009) Effect of vermi-compost on soil fertility and crop productivity-beans (Cycleolus vulgaris). J Environ Bio 30:275-281

Ojeniyi SO (2000) Effect of goat manure on soil nutrients content and okra yield in rainforest area of Nigeria. Appl Trop Agric 5:20-23

Oyeleke SB, Onibagjo HO, Ibrahim K (2003) Degradation of animal wastes (cattle dung) to produce methane (cooking gas). Proceedings of the 5th annual conference of Animal Science of Nigeria (SAN), pp 168-169

Qiu S, McComb AJ, Bell RW (2008) Ratios of C, N, P in soil water direct microbial immobilization- mineralization and $\mathrm{N}$ availability in nutrient amended sandy soil in south western
Australia. Agric Eco Environ 127:93-99. https://doi.org/10.1016/j. agee.2008.03.002

Sajal R, Abul Kashem MD (2014) Effects of organic manures in changes of some soil properties at different incubation periods. Open J Soil Sci 4:81-86. https://doi.org/10.4236/ojss.2014.43011

Saka HB, Azeez JO, Odedina JN, Akinsete SJ (2017) Dynamics of soil nitrogen availability indices in a sandy clay loam soil amended with animal manures. Int J Recycl Org Waste Agric 6:167-178. https://doi.org/10.1007/s40093-017-0165-7

Teppei K, Arata K, Manabu Y (2012) The chemical characteristics of ashes from cattle, swine and poultry manure. J Mater Cycl Waste Manag 15(1):106-110. https://doi.org/10.1007/s1016 3-012-0089-2

USDA (2010) Soil texture calculator. United State development of agriculture natural resources conservation service soils. http://www. nrcs.usda.gov/wps

Vel AM, Swarnam TP (2013) Nitrogen release pattern from organic manures applied to an acid soil. J Agric Sci 5(6):174-184. https ://doi.org/10.5539/jas.v5n6p174

Yusiharni BE, Ziadi H, Gilkes RJ (2007) A laboratory and glasshouse evaluation of chicken litter ash, wood ash and iron smelting slag asliming agents and P fertilizers. Aust J Soil Res 45:374-389. https://doi.org/10.1071/sr06136

Publisher's Note Springer Nature remains neutral with regard to jurisdictional claims in published maps and institutional affiliations. 